\title{
Hydrochemical Evolution Mechanisms of Shallow Groundwater and Its Quality Assessment in the Estuarine Coastal Zone: A Case Study of Qidong, China
}

\author{
Yao Wen, Jiahao Qiu, Si Cheng, Changchang Xu and Xiaojiang Gao * \\ Department of Environmental Science and Engineering, Fudan University, Shanghai 200433, China; \\ 17210740015@fudan.edu.cn (Y.W.); wxthhpzl@126.com (J.Q.); 18210740038@fudan.edu.cn (S.C.); \\ 19210740063@fudan.edu.cn (C.X.) \\ * Correspondence: xjgao@fudan.edu.cn; Tel.: +86-021-31248968
}

Received: 24 April 2020; Accepted: 5 May 2020; Published: 12 May 2020

\begin{abstract}
Identification of geochemical characters and the influence of river and seawater on coastal areas are of significant impact on water resources management in coastal areas globally. Thus, it requires careful investigation of the hydrochemical evolution mechanisms and assessment of the quality of shallow groundwater. The study specifically focused on the estuarine coastal zone of Qidong, China, a city located on the Yangtze estuary. Thirty shallow groundwater samples and five surface water samples were collected during a field investigation, and 25 water quality indexes were analyzed. Methods including mathematical statistics, Gibbs figure, Piper diagram, and ionic rations were used to analyze the hydrochemical characteristics and evolution mechanisms. The spatial distribution of key parameters was assessed using a GIS-based spatial gridding technique. Results showed that the shallow groundwater in this estuarine coastal zone is weakly alkaline. The major hydrochemical parameters, including total dissolved solids (TDS), $\mathrm{Na}^{+}$and $\mathrm{Cl}^{-}, \mathrm{Mg}^{2+}$, and $\mathrm{SO}_{4}{ }^{2-}$, displayed similar spatial distributions; the distributions of $\mathrm{Ca}^{2+}$ and $\mathrm{Mg}^{2+}$ were irregular; the distributions of $\mathrm{SO}_{4}{ }^{2-}$ and $\mathrm{HCO}_{3}{ }^{-}$shared a similar trend, increasing gradually from the southern to northern regions of the study zone; and the values of $\mathrm{NO}_{3}{ }^{-}$and $\mathrm{NH}_{4}{ }^{+}$were generally low in the study area. The hydrochemistry of the groundwater consists of $\mathrm{HCO}_{3}-\mathrm{CaMg}$ type and $\mathrm{HCO}_{3}-\mathrm{Na}$, with $\mathrm{HCO}_{3} \cdot \mathrm{Cl}-\mathrm{Na}$ type and $\mathrm{Cl}-\mathrm{Na}$ being the dominant constituents toward the coastal strip. The coastal aquifers are subjected to the ongoing influence of seawater intrusion, ion exchange processes, freshwater infiltration, and mineral (carbonate and silicate) dissolution, which impact groundwater evolution. Most of the groundwater samples are unsuitable for drinking purposes, but more than $90 \%$ of samples have irrigation suitability, based on the WHO standards and the classifications of sodium absorption ratio (SAR), soluble-sodium percentage (SSP).
\end{abstract}

Keywords: hydrochemistry; shallow groundwater; coastal zone; Yangtze estuary; groundwater quality

\section{Introduction}

In general, estuarine coastal zones are a hotspot for economic development and trade, industrial activity, and population aggregation. Additionally, groundwater is a crucial resource for agricultural, industrial, and domestic output, and it has become one of the most significant factors restricting sustainable regional socio-economic development and ecological environmental protection. Groundwater utilization in the coastal provinces of China reached $4.4 \times 10^{10} \mathrm{~m}^{3}$ in 2009 [1]. Coastal areas are often the final discharge zones for regional groundwater flow systems, with the continual 
mixing of coastal groundwater and seawater [2]. However, with ongoing economic development and high-intensity human activity, estuarine coastal zones are subject to significant environment damage, the equilibrium between freshwater and seawater has been compromised, causing many environmental issues, such as water resources pollution, water salinization, groundwater depth decline, declining fresh and marine water quality, seawater intrusion, land degradation, and wetland destruction [3-5].

The direct link between the groundwater in coastal aquifers and seawater presents a unique challenge to groundwater sustainability in coastal regions and has become a primary restraint in groundwater utilization [6]. Groundwater hydrochemistry provides an indication of the chemical composition of groundwater, revealing the nature of groundwater circulation pathways and the entire water flow system. Therefore, a fundamental body of work has focused on investigating the chemical characteristics of coastal groundwater and the distribution of different types of water chemistries [7-10]. There are differences in distribution of lithology, velocity of groundwater flow, geological factors, and recharge water in the groundwater aquifer following the path of recharge area-runoff area-discharge area. The hydrochemical characteristics and evolution of groundwater are influenced by the provenance of lithostratigraphy and sedimentary environment, hydrogeological conditions and runoff factors, as well as external conditions such as climate change, saline-water encroachment, and anthropogenic activities. Up until now, scholars have primarily studied the chemical characteristics of groundwater and the formation and evolution of hydrochemical composition by using such technical methods as mathematical statistics and geo-statistics, the Piper diagram, the ion proportional coefficient, the mineral saturation index, isotope tracers, and hydrogeochemical simulation [11-18]. The Gibbs diagram has also been applied that provides insightful guidance on the formation mechanisms of the hydrochemistry of groundwater $[3,19,20]$. In particular, the salinization of coastal groundwater has received widespread attention [21-23], while the distribution of nutrient salts in the groundwater of coastal regions has also attracted some research interest $[24,25]$. The geo-spatial analysis based on the geospatial mapping techniques as an intuitionistic and convenient approach can yield significant information regarding the origin of groundwater components and the evolution of groundwater salinization [26-29]. These conditions impose significant management challenges and there is a need for effective means and policies to protect the shallow groundwater which is closely related to human life and health.

The Yangtze estuary coastal area has a flat terrain and a large tidal range and is subject to a water dilution process from the Yangtze River, as well as seawater intrusion. The unique geographical location of it is helpful to expand the research field of coastal zone hydrochemistry worldwide and provide reference for similar situations. In addition, it is of great consequence to study the environmental geochemistry of groundwater in coastal areas in order to further understand the environmental evolution of regional groundwater [30]. Therefore, in order to elucidate the interaction mechanisms between coastal groundwater and the environment, it is crucial to study the spatial distribution and evolution rules of coastal groundwater hydrochemistry. In the past, scholars have paid more attention to the environmental biogeochemical behaviors and ecological and environmental effects of heavy metals, nutrients, and other pollutants in the soil/sediment and surface water in the coastal areas of the Yangtze estuary [31,32]. Furthermore, much research has focused on the groundwater in the Yangtze River Delta, but most studies examined the environmental biogeochemical behaviors of soil/sediment and heavy metals, nutrients and other pollutants, general groundwater quality, and seawater intrusion [15,33-36], indicating that groundwater in Qidong has been subject to severe overexploitation and seawater intrusion. Nonetheless, few studies have examined the chemical characteristics of shallow groundwater in the Yangtze River Delta and estuarine coastal areas, in which aquifers have been subject to the natural impacts of both the Yangtze River and the sea. In recent years, the extent of saltwater intrusion in the Yangtze River estuary has increased significantly due to the impoundment of the Three Gorges Dam [37]. Salinization is one of the important factors for reducing water quality. Knowledge on hydrochemical characteristics is crucial to assess the groundwater quality for understanding the suitability for domestic and irrigation purposes [38]. 
This paper examines the shallow groundwater in the Qidong City coastal area (an annular area $10 \mathrm{~km}$ from the coastline) as the research object, studying its geochemical characteristics and analyzing the influence of river and seawater on coastal areas in order to provide significant information to assist water resources management in coastal areas of Yangtze River estuaries, and other similar coastal areas globally. The purpose of this study is based on the chemical characteristics of shallow groundwater in a coastal plain environment to identify major differences in the water chemistries of such environments, to determine hydrochemical evolution mechanisms, and to assess the quality of shallow groundwater. The present work will be useful for making a database for the long-term use of groundwater, management, and the future strategy to protect the water resources of the region in changing climatic scenarios. It could enable planners and policy makers to develop strategies to mitigate the impact of external factors on shallow groundwater resources and improve the groundwater quality.

\section{Materials and Methods}

\subsection{Study Area}

The coastal area of Qidong City, north of the Yangtze River estuary, was selected as the study area (Figure 1). Qidong City lies in the easternmost part of Jiangsu Province, which is located in southeastern China, belonging to the Yangtze River Delta hydrogeological and sedimentary area. The southwestern part of the study area, situated in the north wing of the Yangtze River estuary, has a geomorphology dominated by a fluviatile coastal plain. The eastern and northern parts of this area are marine plain, which is on the verge of the Yellow Sea, and the southern region is on the northern branch of the Yangtze River estuary.

The study area has a northern subtropical humid climate, with many characteristics of a maritime monsoon climate. Over the period $1981-2010$, the average temperature was $15.6^{\circ} \mathrm{C}$, the average temperature of the coldest month was $-1.9^{\circ} \mathrm{C}$, and the average temperature of the hottest month was $33.2^{\circ} \mathrm{C}$. The annual average precipitation was $1112.0 \mathrm{~mm}$, of which the monthly precipitation from May to September was $697.3 \mathrm{~mm}$, accounting for $62.7 \%$ of the annual precipitation.

The study area belongs to the Yangtze River Delta plain, which is a low-lying area with a surface elevation of 2.0-6.0 m above sea level. The topography of the micro-area is slightly undulating, with a slight dip from northwest to southeast. The north-south gradient is about $1 / 30,000 \mathrm{~m}$ and the gradient of the east-west is about $1 / 43,500 \mathrm{~m}$. Therefore, it is speculated from a general perspective that the groundwater in this region is transported from northwest to southeast and discharged into the sea in the coastal area.

The study area is covered by Quaternary strata and belongs to the hydrogeological zone of the Yangtze River Delta. With the influence of the Yangtze River and the Yellow Sea, it is mainly composed of coastal and estuarine sediments, including littoral-marine (mostly sands) and fluvial-deltaic material (mostly silt, clay, sand, and gravel). Furthermore, the aquifers in the study area are composed of Quaternary Holocene sediments with a thickness of 200-300 m and are characterized by a multi-cycle paralic-sedimentary deposit. This thick and loose strata with a multi-sand layer and good permeability provides favorable conditions for the formation of pore groundwater so that large amounts of loose rock pore water, with a complex water quality and multiple layers, are widely distributed in the littoral zone. According to the age of aquifer, the characteristics of aquifer medium, hydraulic properties, and the depth of groundwater circulation, loose pore water in the area can be divided into three aquifer systems. From top to bottom, it is the Holocene aquifer system (saturated aquifer), the Upper and Middle Pleistocene aquifer system (I-III confined aquifers), and the Early Pleistocene aquifer system (IV-V confined aquifer), respectively [33]. Since mainly shallow groundwater samples were collected in this study, and the depth of the sample wells are $4.5-5 \mathrm{~m}$, the groundwater samples collected are mainly from the Holocene aquifer system, which is a saturated aquifer. Therefore, this article will introduce the hydrogeological characteristics of the saturated aquifer. 


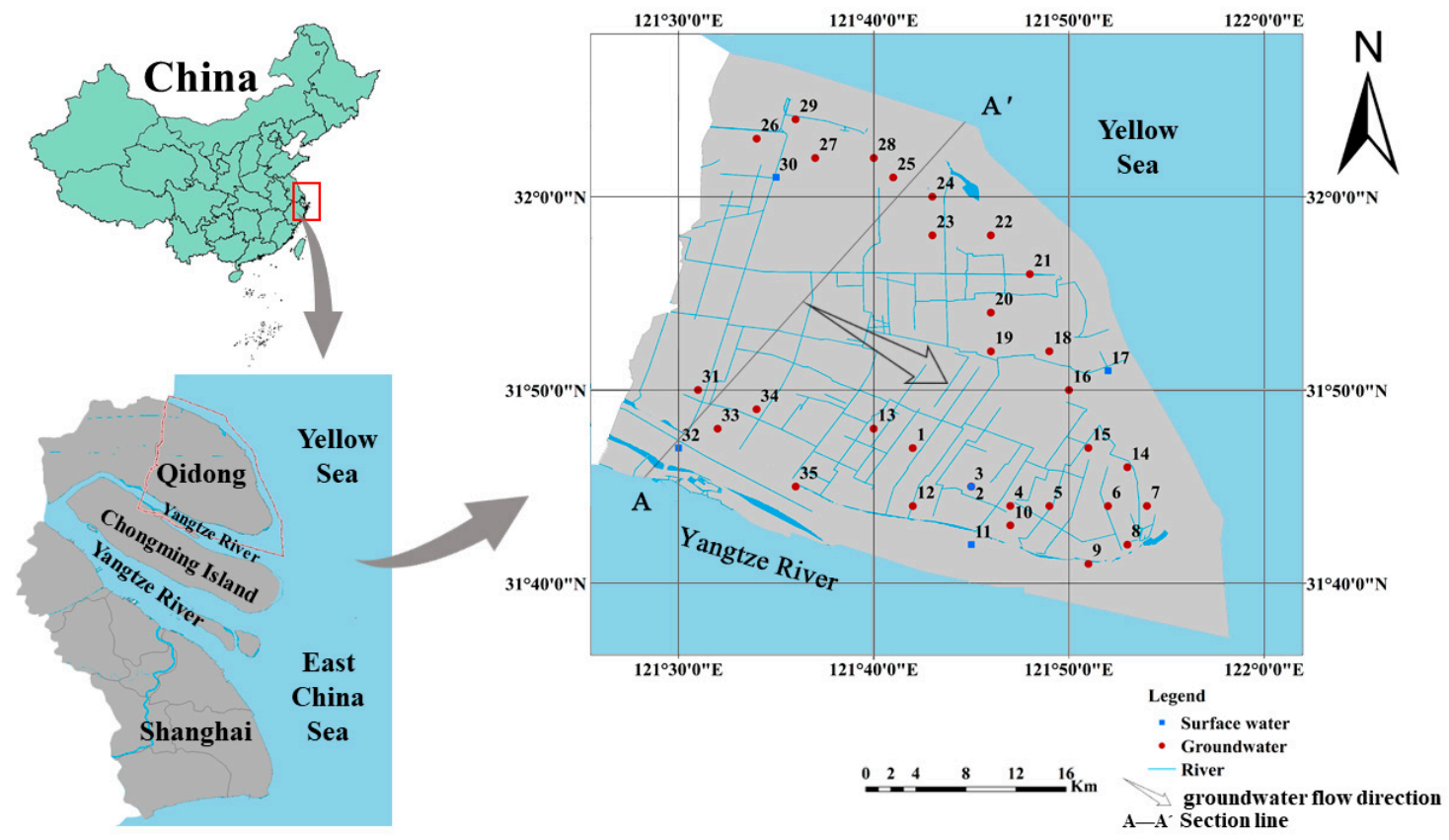

(a)

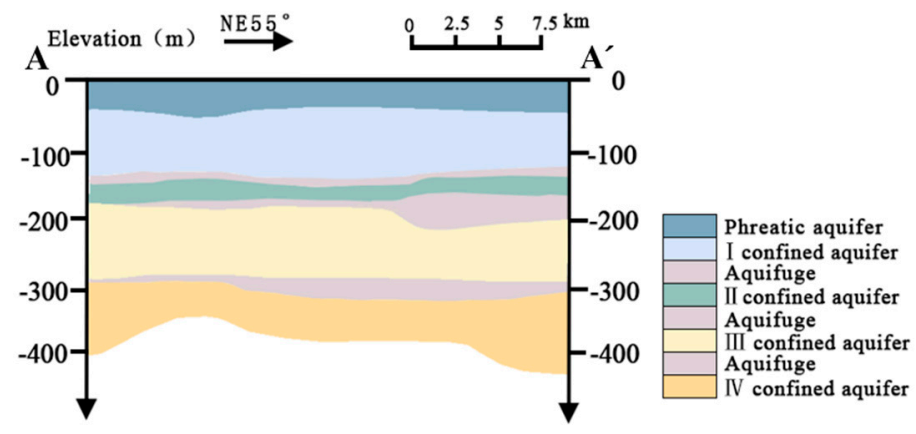

(b)

Figure 1. Location of study area and well sampled in the littoral zone of Qidong (a), hydrogeological cross section of study area (b) (modified from [39]).

The saturated aquifers of the study area are paralic sediments. The lithology of it could be divided into upper and lower sections: the upper section is interbedded by silty sand, sabulous clay and loam, the lower section is loam mixed with powdery sand $[33,40]$. The saturated aquifer floor has a buried depth of 15-35 m, with a thickness of about 15-35 m, and the buried depth of groundwater table is $1-3 \mathrm{~m}$. The horizontal and vertical hydraulic conductivity of the saturated aquifer are $3 \times 10^{-4}-8 \times 10^{-4} \mathrm{~m} / \mathrm{d}$ and $3 \times 10^{-5}-8 \times 10^{-5} \mathrm{~m} / \mathrm{d}$, respectively [41]. The water inflow in a single well is generally $100 \mathrm{~m}^{3} / \mathrm{d}$ [33].

In natural conditions, saturated water table is strikingly controlled by topography. The overall flow direction of the shallow groundwater in study area is from northwest to southeast, and the hydraulic gradient is $0.04 \%$ o- $2 \%$. Due to the gentle terrain, the horizontal runoff of shallow groundwater is very slow, with an average runoff velocity of $0.2 \mathrm{~mm} / \mathrm{d}$ [42]. Owing to the shallow buried depth of saturated water, this area is mainly recharged by atmospheric precipitation, river channel infiltration, agricultural irrigation return flow, lateral runoff (from the sea area), and overflow recharge. Most of the surface runoff in the study area is derived from the Yangtze River. Additionally the water table of the Yangtze River is affected by tides. As the tide rises, the shallow groundwater is recharged by the Yangtze River, while the shallow groundwater is discharged into the Yangtze River when the 
tide sets out [43]. Groundwater is mainly discharged by evaporation or subsurface current to the sea. Artificial discharge is also an important way for groundwater to discharge. Most geological surveys have confirmed that the strata in this area are rich in calcite, potassium feldspar, plagioclase but there are basically no evaporative minerals (such as gypsum and halite) [43].

\subsection{Sampling and Measurement}

On August 21-22, 2017, local domestic wells were used as sampling sites for shallow groundwater and the rivers water were as surface water samplings within 5-10 km from the shoreline of Qidong City. A total of 35 water samples were collected in the study area, including 30 groundwater samples and five surface water samples. Temperature $(\mathrm{T})$ and $\mathrm{pH}$ were measured on site, and groundwater sampling was done once field parameters were stabilized. All the groundwater samples collected for chemical analysis were filtered in the field using an ADVANTEC (Collins, Shanghai, China) $0.2 \mu \mathrm{m}$ cellulose-acetate filter before storing in sampling bottles.

All sampling bottles were rinsed with tap water before sampling and soaked in $10 \%$ nitric acid, then rinsed with tap water and deionized water. When taking a water sample, the bottle was rinsed 2-3 times with sampling water. The sample bottles were put into portable refrigerators for storage, and the samples were sent to Shanghai SEP Analytical Services Co., Ltd., for analysis. The method for collecting and storing groundwater samples was followed in accordance with the Water Sample Collection and Storage Method (HZ-DZ-DXS-0002). The groundwater samples were analyzed for total dissolved solids (TDS), total hardness (as $\mathrm{CaCO}_{3}$ ), major elements $\left(\mathrm{Na}^{+}, \mathrm{K}^{+}, \mathrm{Ca}^{2+}, \mathrm{Mg}^{2+}, \mathrm{Cl}^{-}\right.$, $\left.\mathrm{SO}_{4}{ }^{2-}, \mathrm{HCO}_{3}{ }^{-}, \mathrm{NO}_{3}{ }^{-}, \mathrm{NH}_{4}{ }^{+}\right)$, and micro-components $\left(\mathrm{Fe}^{2+}, \mathrm{Mn}^{2+}, \mathrm{Cu}^{2+}, \mathrm{Al}^{3+}, \mathrm{Zn}^{2+}, \mathrm{Hg}^{2+}, \mathrm{Pb}^{2+}\right.$, $\mathrm{As}^{3+}, \mathrm{Cd}^{2+}, \mathrm{Cr}^{6+}, \mathrm{NO}_{2}{ }^{-}$, and $\left.\mathrm{F}^{-}\right)$. The TDS and total hardness were determined by weighing method and EDTA titrimetric method, respectively. The contents of $\mathrm{Na}^{+}, \mathrm{K}^{+}, \mathrm{Ca}^{2+}, \mathrm{Mg}^{2+}, \mathrm{Fe}^{2+}$, and $\mathrm{Hg}^{2+}$ were performed by plasma emission spectrometry. The contents of $\mathrm{Mn}^{2+}, \mathrm{Cu}^{2+}, \mathrm{Al}^{3+}, \mathrm{Zn}^{2+}, \mathrm{Hg}^{2+}, \mathrm{Pb}^{2+}$, $\mathrm{As}^{3+}, \mathrm{Cd}^{2+}$ were carried out using inductively coupled plasma mass spectrometry. The content of $\mathrm{NH}_{4}{ }^{+}$and $\mathrm{Cr}^{6+}$ were detected by Nessler' reagent spectrophotometry and 1, 5-diphenycarbohydrazide spectrophotometry, respectively. Anion concentrations were estimated using standard analytical methods. All water quality parameters were analyzed based on common and standard methods intended for the examination of a variety of water qualities.

In addition, ionic balances (IB error in Table 1) were undertaken on the chemical analyses for quality control purposes [44]. The major ions $\left(\mathrm{Na}^{+}, \mathrm{K}^{+}, \mathrm{Ca}^{2+}, \mathrm{Mg}^{2+}, \mathrm{Cl}^{-}, \mathrm{SO}_{4}{ }^{2-}, \mathrm{HCO}_{3}^{-}, \mathrm{NO}_{3}{ }^{-}\right)$of groundwater samples were used to compute the IB error. Overall error values below $\pm 5 \%$ are the best analytical estimation and the accepted error level is no more than $\pm 10 \%$ [25]. The IB error values of samples varies between $-9.71 \%$ and $8.60 \%$, with an average value of $0.36 \%$ (Table 1 ). A total of $80 \%$ of groundwater samples in study area had IB error values less than $\pm 5 \%$. The balance errors were accurate.

Table 1. Statistical summaries of hydrochemical elements of shallow groundwater in the study area.

\begin{tabular}{cccccc}
\hline Indicators & Mean Value & Standard Deviation & Minimum & Maximum & Variance (\%) \\
\hline $\mathrm{T}\left({ }^{\circ} \mathrm{C}\right)$ & 24.03 & 0.96 & 22.0 & 25.6 & 4.00 \\
$\mathrm{pH}$ & 8.00 & 0.12 & 7.79 & 8.19 & 1.50 \\
$\mathrm{TH}(\mathrm{mg} / \mathrm{L})$ & 383.91 & 127.98 & 152.15 & 708.71 & 33.30 \\
$\mathrm{TDS}(\mathrm{mg} / \mathrm{L})$ & 981.03 & 650.62 & 305.00 & 2520.00 & 66.30 \\
$\mathrm{Na}^{+}(\mathrm{mg} / \mathrm{L})$ & 212.18 & 248.68 & 20.90 & 883.00 & 117.20 \\
$\mathrm{~K}^{+}(\mathrm{mg} / \mathrm{L})$ & 28.09 & 20.08 & 5.39 & 76.30 & 71.50 \\
$\mathrm{Ca}^{2+}(\mathrm{mg} / \mathrm{L})$ & 66.13 & 18.85 & 21.30 & 102.00 & 28.50 \\
$\mathrm{Mg}^{2+}(\mathrm{mg} / \mathrm{L})$ & 46.43 & 20.33 & 12.20 & 107.00 & 43.80 \\
$\mathrm{Cl}^{-}(\mathrm{mg} / \mathrm{L})$ & 209.23 & 300.95 & 12.62 & 1080.00 & 143.80 \\
$\mathrm{HCO}_{3}{ }^{-}(\mathrm{mg} / \mathrm{L})$ & 557.13 & 297.53 & 170.85 & 1780.00 & 53.40 \\
$\mathrm{SO}_{4}{ }^{-}(\mathrm{mg} / \mathrm{L})$ & 83.93 & 58.12 & 12.54 & 250.00 & 69.20 \\
$\mathrm{NO}_{3}{ }^{-}(\mathrm{mg} / \mathrm{L})$ & 7.32 & 7.96 & 0.16 & 33.08 & 108.70 \\
$\mathrm{NH}_{4}{ }^{+}(\mathrm{mg} / \mathrm{L})$ & 0.36 & 0.75 & 0.01 & 3.73 & 208.30 \\
\hline
\end{tabular}


Table 1. Cont.

\begin{tabular}{cccccc}
\hline Indicators & Mean Value & Standard Deviation & Minimum & Maximum & Variance (\%) \\
\hline $\mathrm{NO}_{2}{ }^{-}(\mathrm{mg} / \mathrm{L})$ & 0.158 & 0.296 & 0.0025 & 1.490 & 187.79 \\
$\mathrm{Fe}^{2+}(\mathrm{mg} / \mathrm{L})$ & 0.290 & 0.60 & 0.025 & 3.110 & 207.06 \\
$\mathrm{Mn}^{2+}(\mathrm{mg} / \mathrm{L})$ & 0.108 & 0.14 & 0.002 & 0.654 & 131.97 \\
$\mathrm{Cu}^{2+}(\mathrm{mg} / \mathrm{L})$ & 0.0020 & 0.0028 & 0.00005 & 0.0138 & 142.45 \\
$\mathrm{Al}^{3+}(\mathrm{mg} / \mathrm{L})$ & 0.214 & 0.198 & 0.0003 & 0.061 & 92.87 \\
$\mathrm{Zn}^{2+}(\mathrm{mg} / \mathrm{L})$ & 0.012 & 0.011 & 0.003 & 0.051 & 95.57 \\
$\mathrm{Hg}^{2+}(\mathrm{mg} / \mathrm{L})$ & 0.00011 & 0.00006 & 0.00005 & 0.00023 & 54.54 \\
$\mathrm{~Pb}^{2+}(\mathrm{mg} / \mathrm{L})$ & 0.00032 & 0.00024 & 0.00003 & 0.00129 & 74.77 \\
$\mathrm{As}^{3+}(\mathrm{mg} / \mathrm{L})$ & 0.0033 & 0.0074 & 0.00004 & 0.0354 & 223.119 \\
$\mathrm{Cd}^{2+}(\mathrm{mg} / \mathrm{L})$ & 0.00013 & 0.000031 & 0.000066 & 0.00018 & 24.75 \\
$\mathrm{Cr}^{6+}(\mathrm{mg} / \mathrm{L})$ & $\mathrm{ND}$ & $\mathrm{ND}$ & $\mathrm{ND}$ & $\mathrm{ND}$ & - \\
$\mathrm{F}^{-}(\mathrm{mg} / \mathrm{L})$ & 0.414 & 0.141 & 0.21 & 0.91 & 33.98 \\
$\mathrm{IB}$ error $(\%)$ & 0.36 & 4.20 & -9.71 & 8.60 & - \\
\hline
\end{tabular}

IB-ion balance; ND—non-detected.

In the statistical calculations and graphical representations, the non-detected values were substituted with the half of detection limit (DL) value. All statistical analyses were performed with the SPSS 13.0 software. The spatial distributions for groundwater major parameters containing TDS, $\mathrm{Na}^{+}, \mathrm{Cl}^{-}, \mathrm{Ca}^{2+}, \mathrm{HCO}_{3}{ }^{-}, \mathrm{Mg}^{2+}, \mathrm{SO}_{4}{ }^{2-}, \mathrm{NO}_{3}{ }^{-}$, and $\mathrm{NH}_{4}{ }^{+}$were completed with the support of spatial analyst modules in ArcGIS 9.2 software.

\section{Results}

\subsection{Hydrochemical Constituents of Shallow Groundwater}

The statistical analysis of the hydrochemical elements and microelements of shallow groundwater is shown in Table 1.

As shown in Table 1, the temperature of shallow groundwater variation ranged from 22.0 to $25.6{ }^{\circ} \mathrm{C}$ with an average value of $24.03^{\circ} \mathrm{C}$. The TDS values ranged from 305 to $2520 \mathrm{mg} / \mathrm{L}$ with a mean value of $981 \mathrm{mg} / \mathrm{L}$. The samples sites \#22 and \#29 had the highest TDS values at 2520 and $2510 \mathrm{mg} / \mathrm{L}$, respectively. Additionally, the $\mathrm{pH}$ of the shallow groundwater in the study area varied only slightly, ranging from 7.79 to 8.19 , indicating the groundwater is slightly alkaline. The total hardness (TH) of the shallow groundwater (calculated as $\mathrm{CaCO}_{3}$ ) in the study area ranged from 152.2 to $708.8 \mathrm{mg} / \mathrm{L}$, with an average of $383.9 \mathrm{mg} / \mathrm{L}$. The total hardness at three locations was extremely high, greater than $550 \mathrm{mg} / \mathrm{L}$. They were sites \#26, \#27, and \#29, and the contents were 575, 560, and $709 \mathrm{mg} / \mathrm{L}$, respectively.

As for the major ions in groundwater, the average values of the $\mathrm{Na}^{+}, \mathrm{K}^{+}, \mathrm{Ca}^{2+}, \mathrm{Mg}^{2+}$, and $\mathrm{NH}_{4}{ }^{+}$in groundwater were $212.18,28.09,66.13,46.43$, and $0.36 \mathrm{mg} / \mathrm{L}$, respectively. Additionally, the $\mathrm{HCO}_{3}{ }^{-}, \mathrm{Cl}^{-}, \mathrm{SO}_{4}{ }^{2-}$, and $\mathrm{NO}_{3}{ }^{-}$had the average values that $557.13,209.23,83.93,7.32 \mathrm{mg} / \mathrm{L}$, respectively. Table 1 shows the average concentration of cations and anions, arranged from highest to lowest, respectively: $\mathrm{Na}^{+}>\mathrm{Ca}^{2+}>\mathrm{Mg}^{2+}>\mathrm{K}^{+}>\mathrm{NH}_{4}{ }^{+}$and $\mathrm{HCO}_{3}{ }^{-}>\mathrm{Cl}^{-}>\mathrm{SO}_{4}{ }^{2-}>\mathrm{NO}_{3}{ }^{-}$. As for the microelements in groundwater, the contents of $\mathrm{Cu}^{2+}, \mathrm{Al}^{3+}, \mathrm{Zn}^{2+}, \mathrm{Hg}^{2+}, \mathrm{Pb}^{2+}, \mathrm{As}^{3+}, \mathrm{Cd}^{2+}$, and $\mathrm{Cr}^{6+}$ in groundwater samples were very low, especially the $\mathrm{Cr}^{6+}$ of all samples was not detected. The value of $\mathrm{NO}_{2}{ }^{-}$in the groundwater ranged from $0.0025 \mathrm{mg} / \mathrm{L}$ to $1.49 \mathrm{mg} / \mathrm{L}$ with an average value of $0.158 \mathrm{mg} / \mathrm{L}$. The concentration of $\mathrm{Fe}^{2+}$ was ranged from 0.025 to $3.11 \mathrm{mg} / \mathrm{L}$ with a mean value of $0.29 \mathrm{mg} / \mathrm{L}$. The average concentration of $\mathrm{Mn}^{2+}$ was $0.108 \mathrm{mg} / \mathrm{L}$ and maximum value of $0.654 \mathrm{mg} / \mathrm{L}$. The content of $\mathrm{F}^{-}$was observed from 0.21 and $0.91 \mathrm{mg} / \mathrm{L}$ with an average value of $0.414 \mathrm{mg} / \mathrm{L}$.

The coefficient of variation (CV), a dimensionless quantity, is used to characterize the variation of spatial scale in hydrogeological variables and provide a measure of the variability of a sample without reference to the scale of the data. It can provide clues about the determinants of the geographical distribution of major elements. A coefficient of variation ranging from $0 \%$ to $10 \%$ generally indicates a weak variation, $10 \%<\mathrm{CV} \leq 100 \%$ means a medium variation, and $\mathrm{CV}>100 \%$ suggests a strong variation. When hydrochemical elements have a CV greater than $100 \%$, they have likely been affected by 
external environmental conditions, such as hydrogeological conditions, topography, hydrometeorology, and human activities, reflecting large spatial changes in groundwater content and indicating significant sensitivity to environmental changes [45].

By analyzing the variability of each major ion, it can be concluded that the $\mathrm{CV}$ of $\mathrm{Ca}^{2+}, \mathrm{Mg}^{2+}, \mathrm{K}^{+}$, $\mathrm{SO}_{4}{ }^{2-}$, and $\mathrm{HCO}_{3}{ }^{-}$was relatively small and stable, indicating that these five ions are less affected by human activities, and more by the natural environment. Furthermore, $\mathrm{Na}^{+}, \mathrm{Cl}^{-}, \mathrm{NO}_{3}{ }^{-}$, and $\mathrm{NH}_{4}{ }^{+}$ had a strong overall spatial variability with CVs greater than $100 \%$, especially $\mathrm{NH}_{4}{ }^{+}$, which had a CV value of $208.3 \%$ indicating that these four ions are greatly affected by human activities and the natural environment. The $\mathrm{CV}$ values of $\mathrm{Na}^{+}$and $\mathrm{Cl}^{-}$were $117.2 \%$ and $143.8 \%$, respectively, indicating a strong variability. It can be inferred from the geographical location of the research area that the distribution of sampling points is concentrated on the Yangtze River bank or on the eastern seashore bank. Therefore, the groundwater could be under the influence of seawater mixing. The high $\mathrm{CV}$ of $\mathrm{NO}_{3}{ }^{-}$and $\mathrm{NH}_{4}{ }^{+}$ indicates that some sampling sites are significantly affected by pesticides, fertilizers, and livestock waste, causing large spatial variations [46].

Correlation analysis can reveal the similarity and heterogeneity of groundwater hydrochemical parameters and reflect similarities and differences in their origins. A Spearman correlation and regression analysis were performed with SPSS 13.0 software. Statistically significant effects were defined as $p<0.01$. It can be seen from Table 2 that TDS is prominently correlated with $\mathrm{Na}^{+}, \mathrm{K}^{+}$, $\mathrm{Mg}^{2+}, \mathrm{SO}_{4}{ }^{2-}, \mathrm{HCO}_{3}{ }^{-}$, and $\mathrm{Cl}^{-}$, indicating the significant contributions of these elements to shallow groundwater mineralization. There was a significant correlation between $\mathrm{Cl}^{-}$and the major ions $\left(\mathrm{K}^{+}\right.$, $\mathrm{Na}^{+}, \mathrm{Mg}^{2+}$, and $\left.\mathrm{HCO}_{3}{ }^{-}\right)$, with the strongest correlation found between $\mathrm{Cl}^{-}$and $\mathrm{Na}^{+}(0.936)$. The strong correlation between $\mathrm{Cl}^{-}$and $\mathrm{Na}^{+}$implies that they share the same origin. The chemical composition of shallow groundwater in this area is significantly affected by seawater intrusion. The good correlation between $\mathrm{K}^{+}-\mathrm{Na}^{+}$and $\mathrm{Ca}^{2+}-\mathrm{Mg}^{2+}$ manifested that they were influenced by the same factors. $\mathrm{HCO}_{3}{ }^{-}$ is poorly correlated to $\mathrm{Ca}^{2+}$ indicating another source other than the calcite dissolution. The poor correlation between $\mathrm{Na}^{+}$and $\mathrm{Ca}^{2+}$ is mainly due to the fact that the area is located at the coastal sea and land junction, and has been affected by seawater and land freshwater for a long time. It is easy to be affected by the external environment and cause water-rock ion exchange in the aquifer [33]. Additionally, there was a low correlation between $\mathrm{Ca}^{2+}$ and $\mathrm{SO}_{4}{ }^{2-}$, which revealed the concentrations of these two ions were controlled by mechanisms other than the dissolution of the gypsum. It confirmed the absence of evaporative minerals in the study area. $\mathrm{NO}_{3}{ }^{-}$was negatively correlated with $\mathrm{NH}_{4}{ }^{+}$and $\mathrm{NO}_{2}{ }^{-}$while $\mathrm{NH}_{4}{ }^{+}$was positively correlated with $\mathrm{NO}_{2}{ }^{-}$, reflecting the complicated transformation of three nitrogens. $\mathrm{NO}_{3}{ }^{-}$was negatively correlated with $\mathrm{Fe}^{2+}$ and $\mathrm{As}^{3+}$. The positive correlation existed in $\mathrm{Fe}-\mathrm{NH}_{4}{ }^{+}, \mathrm{Fe}-\mathrm{NO}_{2}{ }^{-}, \mathrm{Mn}-\mathrm{NH}_{4}{ }^{+}, \mathrm{Cu}-\mathrm{NO}_{3}{ }^{-}, \mathrm{Zn}-\mathrm{Al}$, and $\mathrm{Fe}-\mathrm{As}$. 
Table 2. Correlation matrices of hydrochemical parameters of shallow groundwater.

\begin{tabular}{|c|c|c|c|c|c|c|c|c|c|c|c|c|c|c|c|c|c|c|c|c|c|c|c|}
\hline & $\mathrm{pH}$ & TH & TDS & $\mathrm{Na}^{+}$ & $\mathrm{K}^{+}$ & $\mathrm{Ca}^{2+}$ & $\mathrm{Mg}^{2+}$ & $\mathrm{Cl}^{-}$ & $\mathrm{HCO}_{3}{ }^{-}$ & $\mathrm{SO}_{4}{ }^{2-}$ & $\mathrm{NO}_{3}^{-}$ & $\mathrm{NH}_{4}{ }^{+}$ & $\mathrm{NO}_{2}^{-}$ & $\mathrm{Fe}^{2+}$ & $\mathrm{Mn}^{2+}$ & $\mathrm{Cu}^{2+}$ & $\mathrm{Al}^{3+}$ & $\mathrm{Zn}^{2+}$ & $\mathrm{Hg}^{2+}$ & $\mathrm{Pb}^{2+}$ & $\mathrm{As}^{3+}$ & $\mathrm{Cd}^{2+}$ & $\mathrm{F}^{-}$ \\
\hline $\mathrm{pH}$ & 1.000 & -0.265 & 0.011 & 0.064 & 0.019 & -0.137 & -0.203 & 0.118 & -0.065 & 0.062 & 0.136 & $-0.365^{*}$ & -0.211 & -0.185 & -0.591 & 0.149 & 0.518 & 0.426 & -0.017 & 0.427 & -0.118 & 0.056 & 0.389 \\
\hline TH & & 1.000 & 0.612 & 0.434 & 0.677 & 0.772 & 0.919 & 0.414 & 0.676 & 0.766 & 0.272 & 0.106 & -0.205 & -0.126 & 0.415 & -0.193 & -0.616 & -0.324 & -0.103 & -0.374 & 0.006 & 0.150 & 0.044 \\
\hline TDS & & & 1.000 & 0.788 & 0.829 & 0.261 & 0.708 & 0.768 & 0.677 & 0.683 & 0.183 & 0.194 & 0.056 & -0.127 & 0.258 & -0.044 & -0.273 & -0.097 & -0.145 & 0.042 & 0.172 & 0.376 & 0.406 \\
\hline $\mathrm{Na}^{+}$ & & & & 1.000 & 0.747 & -0.036 & 0.575 & 0.911 & 0.707 & 0.616 & -0.052 & 0.340 & 0.279 & 0.146 & 0.175 & -0.021 & -0.187 & -0.222 & -0.092 & -0.025 & 0.301 & 0.463 & 0.353 \\
\hline $\mathrm{K}^{+}$ & & & & & 1.000 & 0.228 & 0.808 & 0.693 & 0.700 & 0.778 & 0.252 & 0.272 & 0.127 & -0.097 & 0.301 & 0.032 & -0.305 & -0.276 & 0.004 & 0.017 & 0.013 & 0.571 & 0.548 \\
\hline $\mathrm{Ca}^{2+}$ & & & & & & 1.000 & 0.529 & 0.038 & 0.253 & 0.429 & 0.406 & -0.146 & -0.535 & -0.254 & 0.122 & -0.099 & -0.317 & 0.068 & -0.137 & -0.204 & -0.213 & -0.074 & -0.142 \\
\hline $\mathrm{Mg}^{2+}$ & & & & & & & 1.000 & 0.515 & 0.786 & 0.821 & 0.233 & 0.178 & -0.054 & -0.093 & 0.402 & -0.225 & -0.669 & -0.446 & -0.028 & -0.370 & 0.112 & 0.251 & 0.156 \\
\hline $\mathrm{Cl}^{-}$ & & & & & & & & 1.000 & 0.531 & 0.491 & 0.019 & 0.239 & 0.075 & 0.002 & 0.066 & 0.031 & -0.147 & -0.086 & -0.094 & -0.136 & 0.253 & 0.361 & 0.381 \\
\hline $\mathrm{HCO}_{3}{ }^{-}$ & & & & & & & & & 1.000 & 0.666 & -0.041 & 0.412 & 0.163 & 0.242 & 0.349 & -0.273 & -0.403 & -0.362 & 0.045 & -0.171 & 0.321 & 0.245 & 0.218 \\
\hline $\mathrm{SO}_{4}{ }^{2-}$ & & & & & & & & & & 1.000 & 0.245 & -0.068 & -0.090 & -0.204 & 0.241 & -0.101 & -0.489 & -0.336 & -0.152 & -0.074 & -0.112 & 0.419 & 0.275 \\
\hline $\mathrm{NO}_{3}^{-}$ & & & & & & & & & & & 1.000 & -0.493 & -0.465 & -0.746 & -0.418 & 0.682 & 0.010 & 0.251 & -0.082 & 0.232 & -0.703 & 0.088 & 0.081 \\
\hline $\mathrm{NH}_{4}{ }^{+}$ & & & & & & & & & & & & 1.000 & 0.668 & 0.683 & 0.545 & -0.345 & 0.002 & -0.354 & 0.103 & -0.098 & 0.515 & 0.283 & 0.208 \\
\hline $\mathrm{NO}_{2}^{-}$ & & & & & & & & & & & & & 1.000 & 0.549 & 0.329 & -0.175 & 0.071 & -0.287 & -0.087 & 0.091 & 0.480 & 0.311 & 0.091 \\
\hline $\mathrm{Fe}^{2+}$ & & & & & & & & & & & & & & 1.000 & 0.409 & -0.560 & 0.063 & -0.218 & 0.076 & -0.105 & 0.591 & 0.126 & 0.032 \\
\hline $\mathrm{Mn}^{2+}$ & & & & & & & & & & & & & & & 1.000 & -0.499 & -0.494 & -0.475 & 0.097 & -0.330 & 0.359 & 0.045 & -0.046 \\
\hline $\mathrm{Cu}^{2+}$ & & & & & & & & & & & & & & & & 1.000 & 0.358 & 0.394 & -0.240 & 0.447 & -0.628 & 0.065 & 0.204 \\
\hline $\mathrm{Al}^{3+}$ & & & & & & & & & & & & & & & & & 1.000 & 0.644 & -0.180 & 0.630 & -0.172 & 0.053 & 0.259 \\
\hline $\mathrm{Zn}^{2+}$ & & & & & & & & & & & & & & & & & & 1.000 & -0.185 & 0.330 & -0.105 & -0.246 & 0.169 \\
\hline $\mathrm{Hg}^{2+}$ & & & & & & & & & & & & & & & & & & & 1.000 & -0.079 & 0.138 & 0.024 & 0.005 \\
\hline $\mathrm{Pb}^{2+}$ & & & & & & & & & & & & & & & & & & & & 1.000 & -0.368 & 0.374 & 0.277 \\
\hline $\mathrm{As}^{3+}$ & & & & & & & & & & & & & & & & & & & & & 1.000 & -0.098 & -0.083 \\
\hline $\mathrm{Cd}^{2+}$ & & & & & & & & & & & & & & & & & & & & & & 1.000 & 0.488 \\
\hline $\mathrm{F}^{-}$ & & & & & & & & & & & & & & & & & & & & & & & 1.000 \\
\hline
\end{tabular}

Good correlations are represented in bold format. 


\subsection{Hydrochemical Types of Shallow Groundwater and Its Spatial Distribution}

Based on the hydrochemical data from shallow groundwater in Qidong City, the major ion $\left(\mathrm{Na}^{+}\right.$, $\left.\mathrm{K}^{+}, \mathrm{Ca}^{2+}, \mathrm{Mg}^{2+}, \mathrm{HCO}_{3}{ }^{-}, \mathrm{CO}_{3}{ }^{2-}, \mathrm{SO}_{4}{ }^{2-}, \mathrm{Cl}^{-}\right)$concentrations in shallow groundwater samples were plotted in a trilinear Piper diagram [47] to determine the geochemical characteristics of groundwater in the study area. The Piper diagram (Figure 2) shows that $\mathrm{Na}^{+}$is the main cation while $\mathrm{HCO}_{3}{ }^{-}$ dominates in anions. Furthermore, there is a wide range of $\mathrm{Cl}^{-}$and less $\mathrm{SO}_{4}{ }^{2-}$, and a clear trend in cations. The groundwater samples in the study area were classified into four major hydrogeochemical facies, which are $\mathrm{HCO}_{3}$-CaMg (black circle), $\mathrm{Cl}-\mathrm{Na}$ (blue triangle), $\mathrm{HCO}_{3} \mathrm{Cl}-\mathrm{Na}$ (red hollow circle), and $\mathrm{HCO}_{3}-\mathrm{Na}$ (green inverted triangle) types. The majority of the groundwater samples, represented by black circles, occupying the left part of the central diamond graph were determined to be $\mathrm{HCO}_{3}-\mathrm{CaMg}$ water, and $63 \%$ of the total groundwater samples were assigned to this category. The $\mathrm{Cl}-\mathrm{Na}$ water type scattered in the right half of the diamond plot constituted about $17 \%$ of the samples (\#7, \#8, \#14, $\# 22$, and \#29), marked by blue triangles. Samples \#2,\#12,\#19,\#21, and \#24, which are shown as hollow circles in the central diamond plot, belong to a $\mathrm{HCO}_{3} \cdot \mathrm{Cl}-\mathrm{Na}$ water category; the groundwater composition of sample \#25, shown as green inverted triangle, is $\mathrm{HCO}_{3}-\mathrm{Na}$. To sum up, the prevalent type of water in the study area is $\mathrm{HCO}_{3}-\mathrm{CaMg}$, followed by $\mathrm{Cl}-\mathrm{Na}$, and $\mathrm{HCO}_{3} \cdot \mathrm{Cl}-\mathrm{Na}$. Compared to the other samples, these $\mathrm{Cl}-\mathrm{Na}$ water type samples were found closer to the sea coast, where groundwater may have been impacted by seawater intrusion in the shallow aquifer. The groundwater consists of $\mathrm{HCO}_{3}-\mathrm{CaMg}$ and $\mathrm{HCO}_{3}-\mathrm{Na}$, evolving closer to the coastal strip into $\mathrm{HCO}_{3} \cdot \mathrm{Cl}-\mathrm{Na}$ and $\mathrm{Cl}-\mathrm{Na}$, due to the transition of major anions from bicarbonate to bicarbonate chloride and chloride along groundwater pathways, which demonstrates that the quality of shallow groundwater along the coast is affected by seawater intrusion.

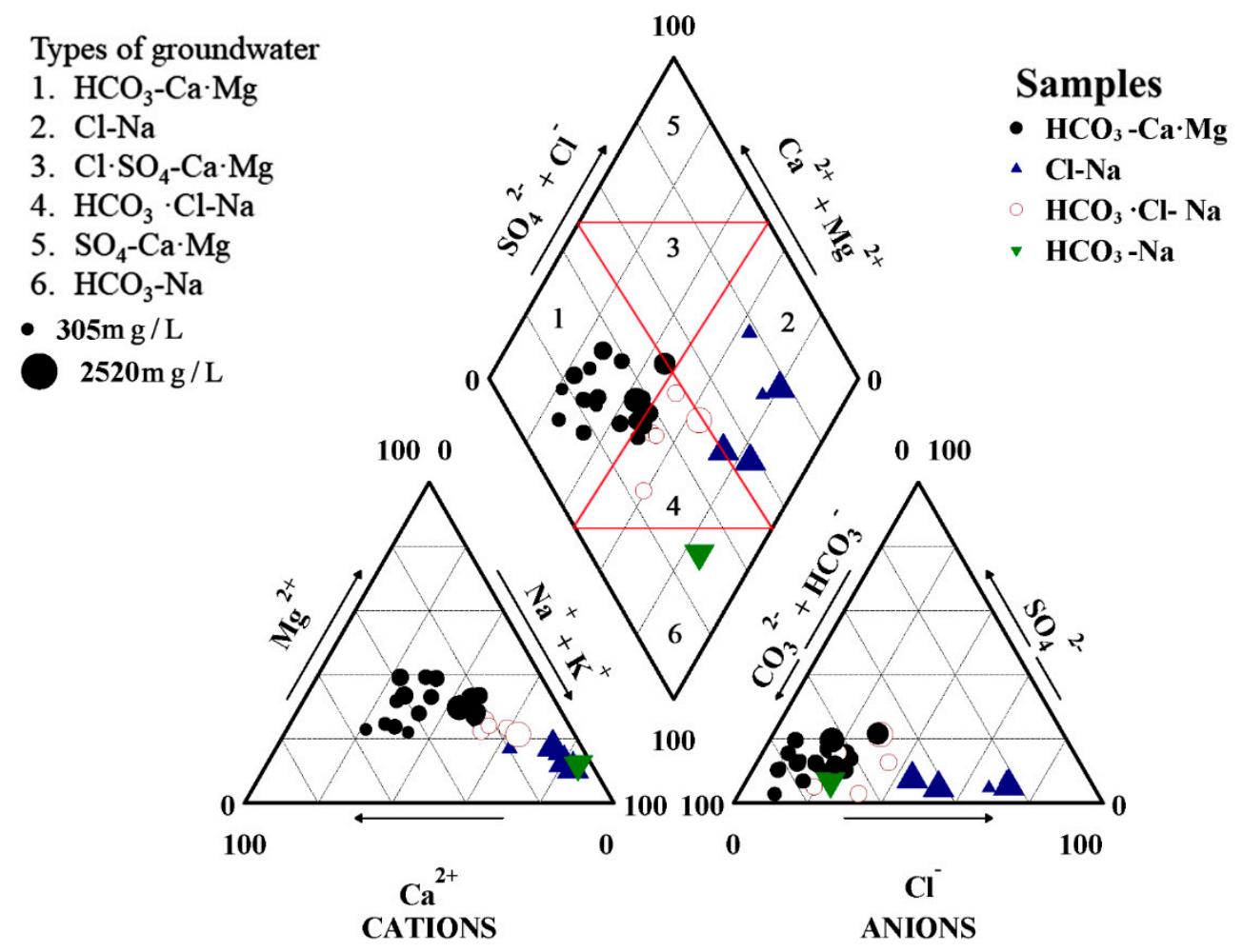

Figure 2. Piper diagram of shallow groundwater. The size of symbols represents the TDS (total dissolved solids).

The comparison of chemical characteristics between surface water and shallow groundwater is significant to understand the impact of surface water on groundwater. It can be seen from Table A1 in Appendix A that the concentrations of major hydrochemical parameters, except $\mathrm{NO}_{3}{ }^{-}$and TDS 
in Wucang Port (\#11) and Xiexing Port (\#17), were significantly higher than those the three other surface water samples, Huiping Town (\#3), Lvsi Town (\#30), and Sanhe Port (\#32). In addition, the water chemistry Piper diagram of surface water and groundwater (Figure A1) intuitively reveals that significant spatial difference in water chemistry characteristics of surface water. The Wucang Port (\#11) and Xiexing Port (\#17) anions were completely dominated by $\mathrm{Cl}^{-}$. The water chemistry type is chloride-sodium (Cl-Na). Wucang Port (\#11) is located in the lower reaches of the Yangtze River, which influenced by seawater mixing processes, while Xiexing Port (\#17) is located on the East China Sea coast, so it already contains saltwater. The chemical characteristics of these surface water samples are roughly identical with those of shallow groundwater surrounding it, confirming the impact of seawater intrusion on water quality in the region. On the other hand, the other three surface water have different water types, $\mathrm{HCO}_{3}-\mathrm{CaMg}$. The differences could be explained by the fact that Sanhe Port (\#32) is situated in the lower reaches of the Yangtze River, upstream of Wucang Port (\#11), and it is less affected by the seawater mixing than Wucang Port (\#11). Furthermore, the surface water samples of Lvsi Town (\#30) and Sanhe Town (\#32) are located inland, and all concentrations were approximately consistent with that of shallow groundwater which is adjacent to the surface water samples, confirming the influence of the phenomena of freshening to the shallow groundwater under natural recharge.

\subsection{Geospatial Distribution of Key Ions in Coastal Zone}

The geological interpretation of key factors may help to determine the spatial distribution of hydrochemical variables in groundwater, which is governed by complicated impact processes. In this study, the major hydrochemical parameters (TDS, $\mathrm{Na}^{+}, \mathrm{Cl}^{-}, \mathrm{Ca}^{2+}, \mathrm{HCO}_{3}{ }^{-}, \mathrm{Mg}^{2+}, \mathrm{SO}_{4}{ }^{2-}, \mathrm{NO}_{3}{ }^{-}, \mathrm{NH}_{4}{ }^{+}$) were gridded using a GIS-based inverse distance weighted (IDW) technical approach to demonstrate the corresponding spatial distribution models (Figures 3 and 4), which are shown as maps.

TDS generally refers to the contents of various components present in the water, including compounds, molecules, and ions [48]. The large variation in TDS concentrations is influenced by diverse processes such as ocean water spray, ions from intruding seawater, seawater and estuarine alluvial aquifers, the influx of river water recharging the surrounding aquifer, mixed ion exchange processes along the ground water flow paths, as well as geological influences, mineralogy diversification, and the geochemical environments. According to the data, most of the shallow groundwater samples on the shore of Qidong City were freshwater (TDS $<1000 \mathrm{mg} / \mathrm{L}$ ), and only a small portion (approximately $23 \%)$ of the total sampling area was brackish water $(1000<$ TDS $<3000 \mathrm{mg} / \mathrm{L})$, which are presented as $\# 14, \# 21, \# 22, \# 26, \# 25, \# 27$, and \#29. The TDS value gradually increased from southwest to northeast, as shown in Figure 2. In combination with the geographical position of the research area, the south bank of the coastal shore of Qidong City is located in the lower reaches of the Yangtze River, and along the Yangtze River, the further east towards the sea, the greater the contribution of seawater mixing in the shallow groundwater, resulting in an increase in TDS content. TDS, $\mathrm{Na}^{+}$, and $\mathrm{Cl}^{-}$(Figures 3 and $4 a, b)$ had similar distribution patterns, where they were high in the northern, northeastern, and southeastern coastal regions, which suggests that $\mathrm{Na}^{+}$and $\mathrm{Cl}^{-}$may be derived from the same source of intruded modern seawater, which has a significant impact on groundwater salinity. The highest values for TDS, $\mathrm{Na}^{+}$, and $\mathrm{Cl}^{-}$were exhibited at site $\# 22$. $\mathrm{Mg}^{2+}$ concentrations in the northwestern of the area were much higher than those in the other regions. $\mathrm{Ca}^{2+}$ displayed a different trend, with the concentrations being high in the west of the study area. However, sample site \#16, located in the eastern margin, had the highest value. It can be seen in Figure $4 c, d$ that the distribution of $\mathrm{Ca}^{2+}$ and $\mathrm{Mg}^{2+}$ is irregular. The concentration of $\mathrm{SO}_{4}{ }^{2-}$ increased gradually from south to north of the study area, and the three highest values of $\mathrm{SO}_{4}{ }^{2-}$ occurred at sample sites \#21, \#26, and \#29. In addition, there was a similar distribution between the $\mathrm{Mg}^{2+}$ and $\mathrm{SO}_{4}{ }^{2-}$, with the high concentrations found in the north of the region along the Yellow Sea coast. Due to the high concentration of $\mathrm{Mg}^{2+}$ and $\mathrm{SO}_{4}{ }^{2-}$ in seawater, and the fact that there were no gypsum minerals present in the study area based on previous geological data, the high content of $\mathrm{Mg}^{2+}$ and $\mathrm{SO}_{4}{ }^{2-}$ in the coastal area was most likely a result of 
seawater intrusion. The $\mathrm{SO}_{4}{ }^{2-}$ may also be affected by natural processes and artificial pollution, like the breakdown of organic substances in weathered soils, sulfate fertilizers, and domestic wastewater [49].

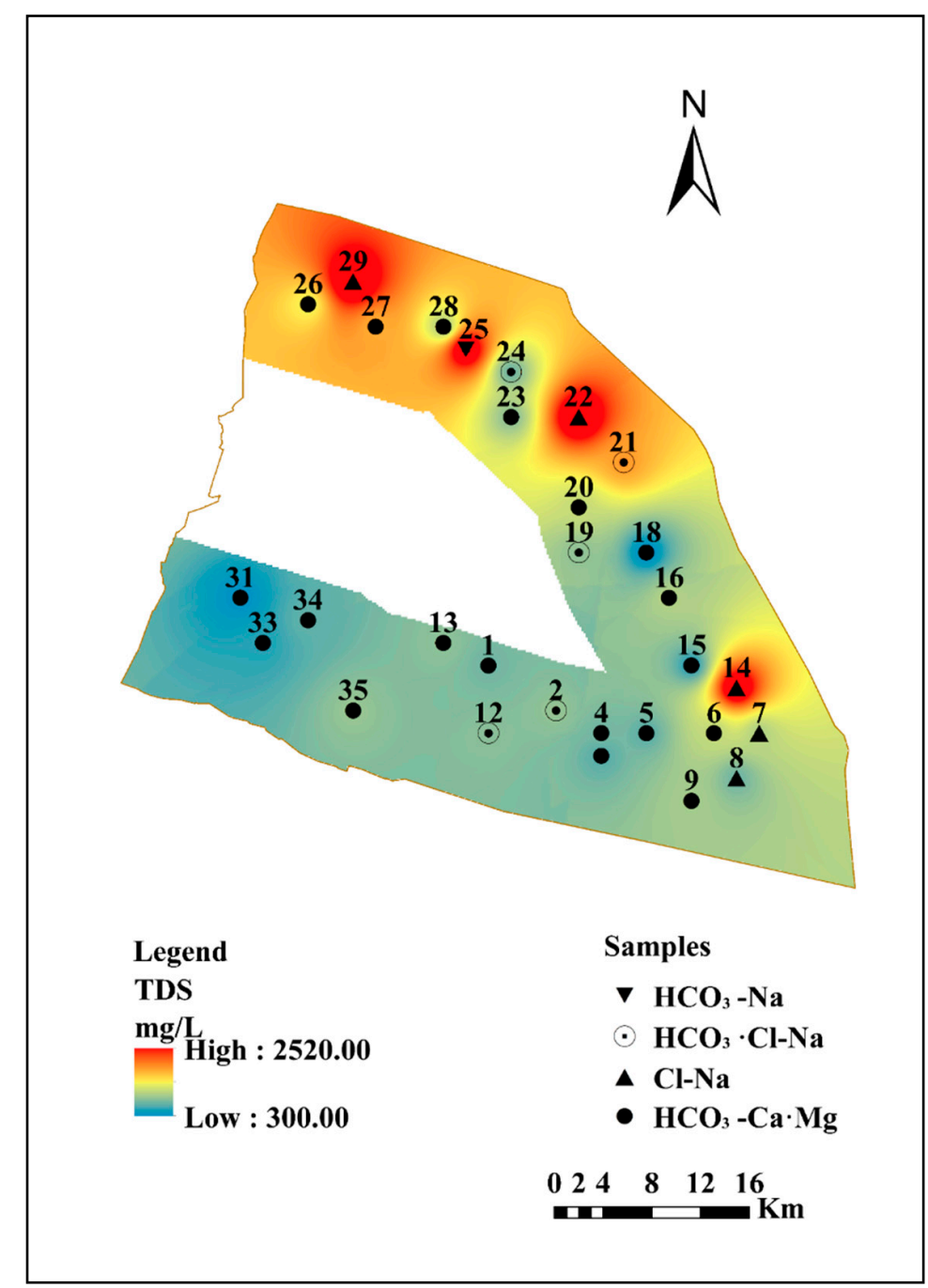

Figure 3. Geospatial distribution of TDS in the study area.

It was noted that the $\mathrm{HCO}_{3}{ }^{-}$ion distribution map (Figure 4f) showed a distinguished enrichment towards the north and the highest value, $1050 \mathrm{mg} / \mathrm{L}$, was recorded at \#14. Nitrate and ammonia concentrations were generally low (most $\mathrm{NO}_{3}{ }^{-}<10 \mathrm{mg} / \mathrm{L}$, most $\mathrm{NH}_{4}{ }^{+}<0.5 \mathrm{mg} / \mathrm{L}$ ). The sample sites $\# 16$ and \#27 were the two locations with the highest $\mathrm{NO}_{3}{ }^{-}$concentrations, and the highest $\mathrm{NH}_{4}{ }^{+}$value was $3.73 \mathrm{mg} / \mathrm{L}$ at sample site \#25. The sample sites \#16, \#25, and \#27 are located in the concentrated residential areas, so that the extraordinarily high nitrate and ammonia concentrations are associated with anthropogenic pollution [50]. 


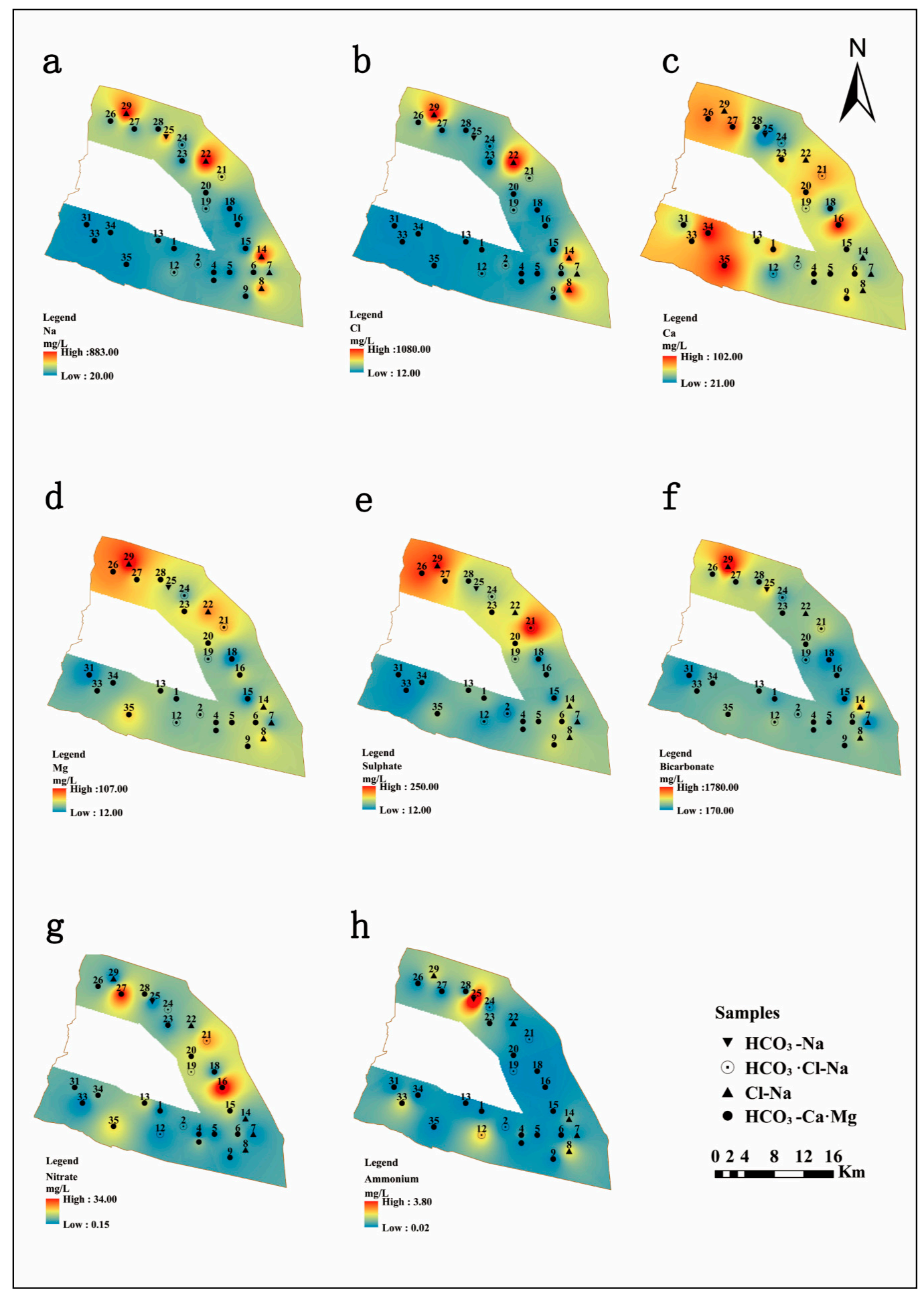

Figure 4. Spatial distribution of the major ion concentrations $(\mathrm{mg} / \mathrm{L})$ in study area: (a) $\mathrm{Na},(\mathbf{b}) \mathrm{Cl}$, (c) $\mathrm{Ca}$, (d) $\mathrm{Mg},(\mathbf{e}) \mathrm{SO}_{4}{ }^{2-}$, (f) $\mathrm{HCO}_{3}{ }^{-}$, (g) $\mathrm{NO}_{3}{ }^{-}$, (h) $\mathrm{NH}_{4}{ }^{+}$.

\section{Discussion}

\subsection{Hydrochemical Evolution Mechanisms}

The Gibbs diagram could provide insightful guidance on the formation mechanisms of the hydrochemistry of groundwater. There are three main mechanisms for controlling the hydrochemical composition of natural water, which are atmospheric precipitation, rock weathering hydrolysis, 
and evaporation concentration, identified from the Gibbs diagram [20]. As shown in Figure 5, the shallow groundwater in this area has a TDS range of $100-5000 \mathrm{mg} / \mathrm{L}$, the $\mathrm{Na}^{+} /\left(\mathrm{Na}^{+}+\mathrm{Ca}^{2+}\right)$ ratio is $0.2-1.0$ overall, and the ratio of $\mathrm{Cl}^{-} /\left(\mathrm{Cl}^{-}+\mathrm{HCO}_{3}{ }^{-}\right)$is generally between 0 and 0.7 . The points were mainly distributed in the upper middle part of the Gibbs diagram. It can, therefore, be concluded that the compositions of shallow groundwater in the study area are predominantly controlled by a combination of evaporation and weathering dissolution of minerals. Moreover, some of the points did not fall completely in line with the Gibbs' classification, indicating that, in addition to the three impact mechanisms mentioned above, there are other factors influencing groundwater chemical composition in the coastal study area. Due to the unique geographical location of the study area, the shallow groundwater in the zone was not only recharged by the freshwater of the Yangtze River but was also impacted by seawater from the East China Sea. It cannot be ignored that the mixing of salty and freshwater is one significant formation mechanism. Complex hydrogeochemical processes in the shallow aquifer ultimately determine the current composition of groundwater.
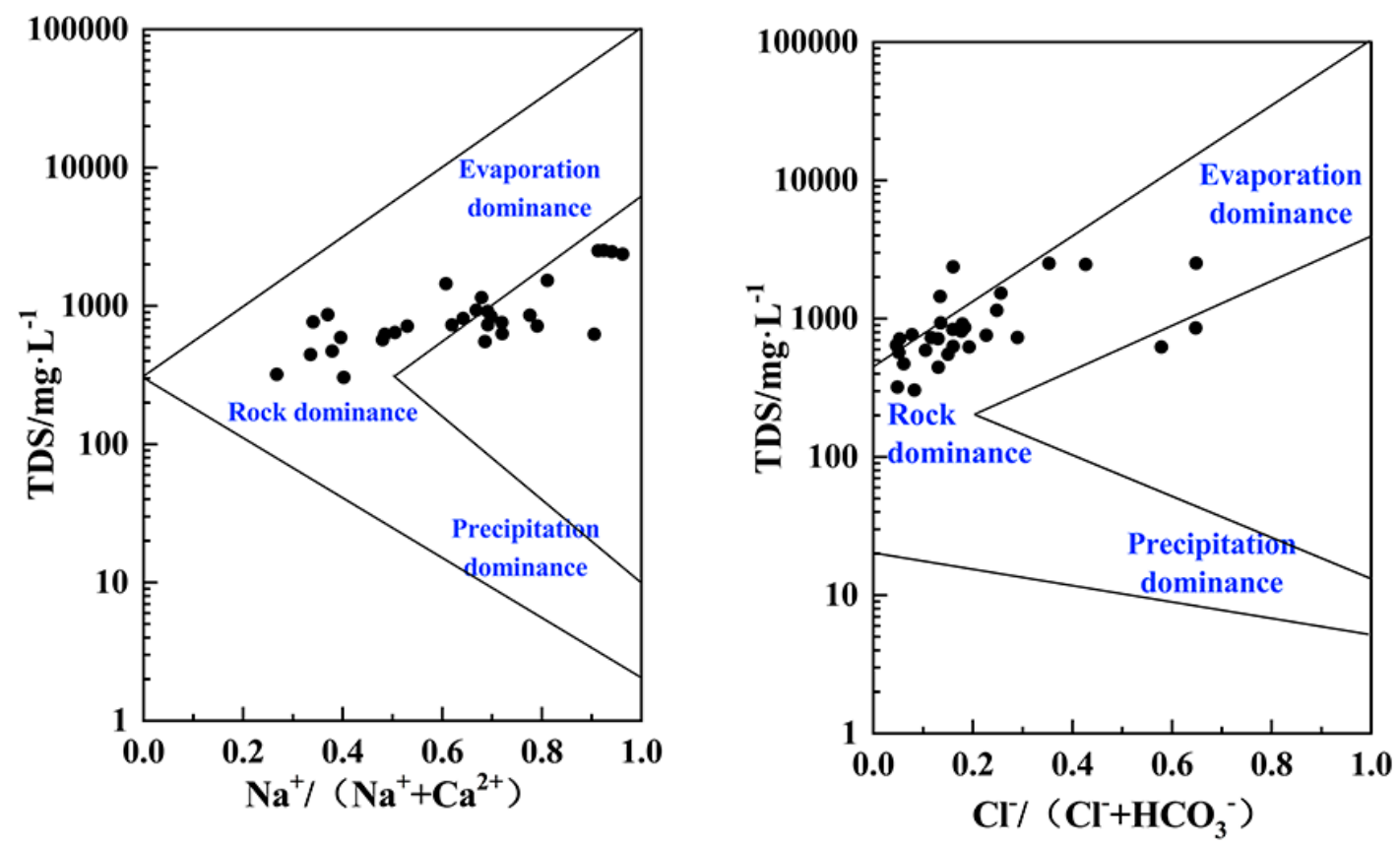

Figure 5. Gibbs diagram of shallow groundwater.

The ions' proportionality coefficient is used for the analysis of groundwater evolution and hydrogeochemical processes. The value of $\mathrm{Na}^{+} / \mathrm{Cl}^{-}$(meq/L) is known as the groundwater genetic coefficient and is widely used to characterize the degree of $\mathrm{Na}^{+}$enrichment in groundwater and for the research on saline intrusion mechanisms in coastal regions [3]. The standard value of $\mathrm{Na}^{+} / \mathrm{Cl}^{-}$ (meq/L) in seawater is 0.86 [51]. Chloride is a conservative element, on which chemical reactions in groundwater and seawater have minimal influence. There are three conclusions that may be drawn from the distribution of the scatter points. Firstly, when the ratio of $\mathrm{Na}^{+} / \mathrm{Cl}^{-}$was near 0.86 it indicated that the salinity in shallow groundwater was most likely derived from the mixing of seawater. Secondly, when the ratio of $\mathrm{Na}^{+} / \mathrm{Cl}^{-}<0.86$, it indicated that the shallow groundwater is in a concentrated metamorphic condition and has the characteristics of paleo-sedimentary water. Thirdly, when the ratio of $\mathrm{Na}^{+} / \mathrm{Cl}^{-}>0.86$, the milliequivalent concentration of $\mathrm{Na}^{+}$was greater than $\mathrm{Cl}^{-}$, and the shallow groundwater was likely impacted by the weathering dissolution of silicate minerals. From the data analysis, it can be deduced that $\mathrm{Na}^{+} / \mathrm{Cl}^{-}$in the study area ranged from 0.87 to 4.67 , and the average value was 2.09, which is greater than the value for standard seawater of 0.86 . Samples of \#7, \#8, and $\# 16$, with $\mathrm{Na}^{+} / \mathrm{Cl}^{-}=0.86$ and located in the southeastern of coastal area, are strongly affected by the modern seawater intrusion. The scatter diagram of the $\mathrm{Na}^{+} / \mathrm{Cl}^{-}$ration versus $\mathrm{Cl}^{-}$(refer to Figure 6a) 
indicates that most of the groundwater samples can be plotted above the line of $\mathrm{Na}^{+} / \mathrm{Cl}^{-}=0.86$, which could suggest that the shallow groundwater in the study area was not only affected by a combination of seawater mixing but also probably by the weathering and dissolution of silicate minerals.

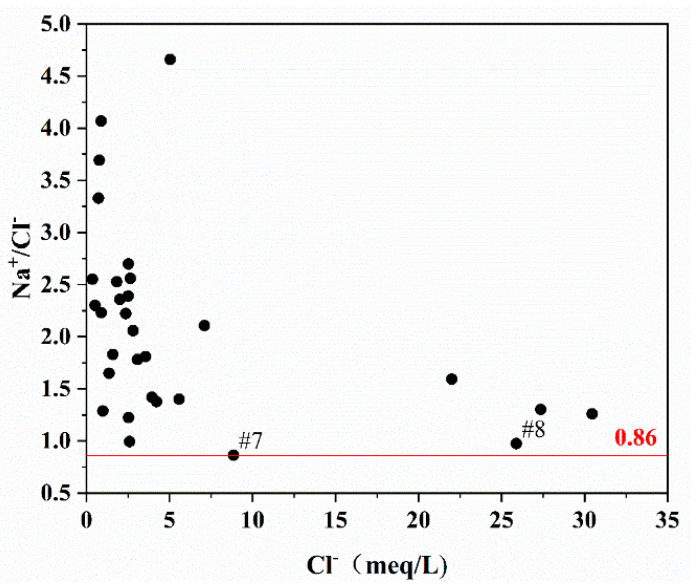

(a)

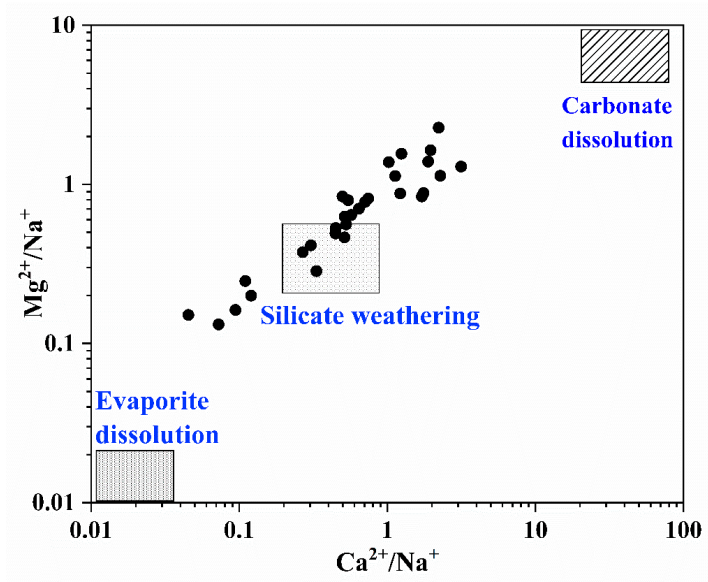

(c)

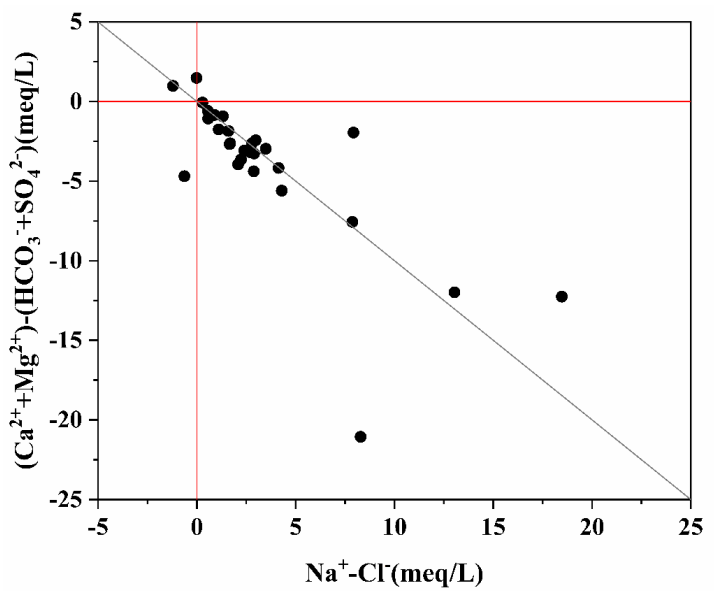

(b)

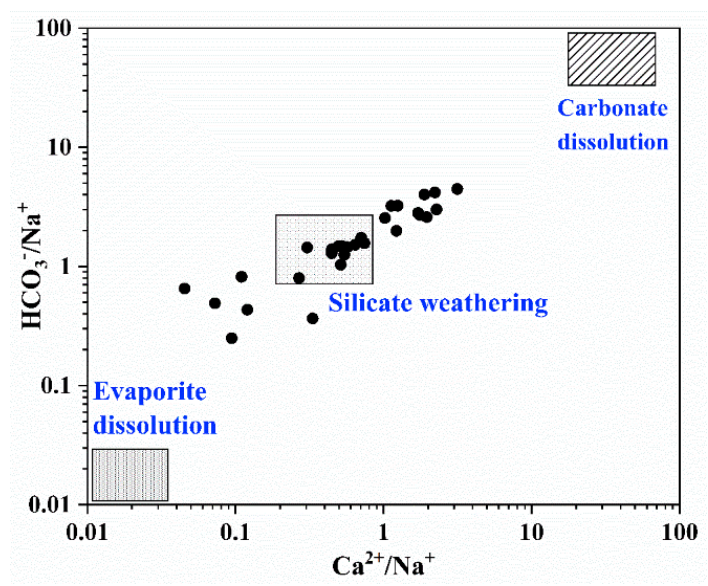

(d)

Figure 6. Scatter diagram of (a) $\mathrm{Na}^{+} / \mathrm{Cl}^{-}$vs. $\mathrm{Cl}^{-}$, (b) $\left[\left(\mathrm{Ca}^{2+}+\mathrm{Mg}^{2+}\right)-\left(\mathrm{HCO}_{3}{ }^{-}+\mathrm{SO}_{4}{ }^{2-}\right)\right] \mathrm{vs} .\left[\mathrm{Na}^{+}-\mathrm{Cl}^{-}\right]$, (c) $\mathrm{Mg}^{2+} / \mathrm{Na}^{+}$vs. $\mathrm{Ca}^{2+} / \mathrm{Na}^{+}$, and (d) $\mathrm{HCO}_{3}{ }^{-} / \mathrm{Na}^{+}$vs. $\mathrm{Ca}^{2+} / \mathrm{Na}^{+}$.

In order to further determine the influence of weathering dissolution of minerals on the hydrochemical evolution in the study area, the $\mathrm{Ca}^{2+} / \mathrm{Na}^{+}, \mathrm{Mg}^{2+} / \mathrm{Na}^{+}$and $\mathrm{HCO}_{3}{ }^{-} / \mathrm{Na}^{+}$were used to identify the carbonate, silicate, and evaporite minerals dissolution [52]. In the scatter diagram of the relationship $\mathrm{Ca}^{2+} / \mathrm{Na}^{+}$relative to $\mathrm{Mg}^{2+} / \mathrm{Na}^{+}$and $\mathrm{Ca}^{2+} / \mathrm{Na}^{+}$relative to $\mathrm{HCO}_{3}{ }^{-} / \mathrm{Na}^{+}$(Figure $6 \mathrm{c}$, $\mathrm{d}$ ), these major cations ratios (meq/L) of groundwater were mainly distributed between the weathering of silicate and dissolution of carbonate minerals. It indicates that the weathering dissolution of silicate and carbonate accounts for the contribution to the hydrochemical evolution of the study area. This finding is in good agreement with the inferences drawn from the Gibbs diagram (Figure 5).

The cation exchange process is another vastly essential process in coastal aquifers, which contributes to the evolution of groundwater composition. Additionally, the negative correlation of $\mathrm{Na}^{+}$and $\mathrm{Ca}^{2+}$ implies the cation exchange process prevailing in the study aquifer. On the other hand, the hydrogeological basin of the Yangtze River Delta alluvial plain is regarded as a favorable environment for the cationic exchange processes in the clay matrix of this aquifer because of the occurrence of montmorillonite clay, which has the good ability to adsorb cations. The scatter diagram (Figure $6 \mathrm{~b})$ of the relationship $\left[\left(\mathrm{Ca}^{2+}+\mathrm{Mg}^{2+}\right)-\left(\mathrm{HCO}_{3}{ }^{-}+\mathrm{SO}_{4}{ }^{2-}\right)\right]$ relative to $\left(\mathrm{Na}^{+}-\mathrm{Cl}^{-}\right)$ 
could determine whether the exchange of $\mathrm{Na}^{+}$against $\left(\mathrm{Ca}^{2+}\right.$ or $\left.\mathrm{Mg}^{2+}\right)$ is occurring through the clay matrix [5,53]. In general, if there is absence of cation exchange, all groundwater samples will be placed in the origin of the diagram. Otherwise, the cationic exchange process controls the chemical parameters of the water, and the relationship between these parameters should be linear with a slope equal to $-1[19,54]$. In consideration of salinity signature, the mixing mechanism is mainly caused by seawater intrusion and the freshening phenomena is due to the cation exchange reaction in the aquifer matrix, in which the clay mineral is the cationic exchanger [55].

The following Equations (1) and (2) show the gain or loss related to $\mathrm{Na}^{+}$and $\left(\mathrm{Ca}^{2+}+\mathrm{Mg}^{2+}\right)$ within the exchanger $X$.

$$
\mathrm{Na}-\mathrm{X}+1 / 2 \mathrm{Ca}^{2+} \rightarrow \mathrm{Na}^{+}+1 / 2 \mathrm{Ca}-\mathrm{X}
$$

represents the freshening.

$$
1 / 2 \mathrm{Ca}-\mathrm{X}+\mathrm{Na}^{+} \rightarrow 1 / 2 \mathrm{Ca}^{2+}+\mathrm{Na}-\mathrm{X}
$$

represents the seawater intrusion.

The scale diagram of $\left[\left(\mathrm{Ca}^{2+}+\mathrm{Mg}^{2+}\right)-\left(\mathrm{HCO}_{3}{ }^{-}+\mathrm{SO}_{4}{ }^{2-}\right)\right]$ vs. $\left(\mathrm{Na}^{+}-\mathrm{Cl}^{-}\right)$in Figure $6 \mathrm{~b}$ shows that most of the groundwater samples scatter around the line of $y=-x$. These shallow groundwater samples are the results of freshening phenomenon under natural recharge conditions and the recharge water tends to flush out the brackish water along the flow path toward the discharge zone [56]. There are samples in Figure 6b concentrated in the origin, which indicated no cation exchange occurs. The reason is the evaporation process followed by carbonate precipitation [57]. Additionally, the cation-exchange process could be characterized by chloro-alkaline index [58]. The calculation formula of chloro-alkaline index CAI-1, CAI-2 is as follows (all ionic concentrations are expressed by meq/L):

$$
\begin{gathered}
\mathrm{CAI}-1=\left[\mathrm{Cl}^{-}-\left(\mathrm{Na}^{+}+\mathrm{K}^{+}\right)\right] / \mathrm{Cl}^{-}, \\
\mathrm{CAI}-2=\left[\mathrm{Cl}^{-}-\left(\mathrm{Na}^{+}+\mathrm{K}^{+}\right)\right] /\left(\mathrm{HCO}_{3}{ }^{-}+\mathrm{SO}_{4}{ }^{2-}+\mathrm{NO}_{3}{ }^{-}\right) .
\end{gathered}
$$

If both CAI-1 and CAI-2 are negative, this indicates that $\mathrm{Ca}^{2+}$ or $\mathrm{Mg}^{2+}$ in the groundwater is exchanged with $\mathrm{Na}^{+}$in aquifer medium (Equation (1)), while if both CAI-1 and CAI-2 are positive, this implies that reverse cation exchange occurs (Equation (2)). As shown in Figure 7, most chlor-alkali indexes are less than 0 , exhibiting that exchange between $\mathrm{Ca}^{2+}$ and $\mathrm{Mg}^{2+}$ in groundwater and $\mathrm{Na}^{+}$ in water-bearing media mainly prevails in the study area. The same result is also noted using the relationship $\left[\left(\mathrm{Ca}^{2+}+\mathrm{Mg}^{2+}\right)-\left(\mathrm{HCO}_{3}{ }^{-}+\mathrm{SO}_{4}{ }^{2-}\right)\right]$ relative to $\left(\mathrm{Na}^{+}-\mathrm{Cl}^{-}\right)$(Figure 6) and Gibbs diagrams (Figure 5).

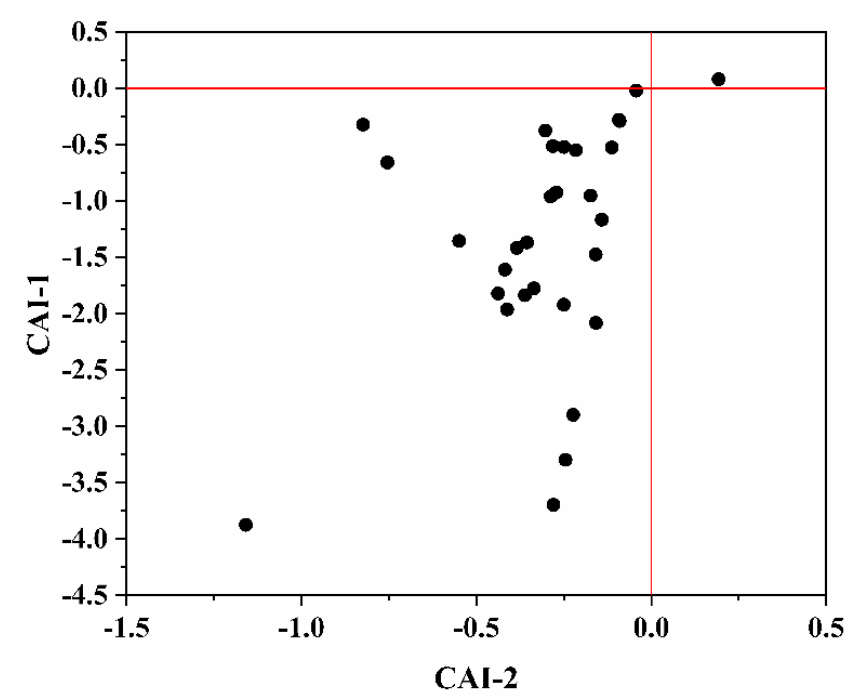

Figure 7. Chloro-alkaline indices of shallow groundwater. 
As the saturated aquifer of Yangtze River estuarine coastal area supports irrigation activity and the relatively concentrated residential area in coastal areas, the study area is subject to contamination by nitrate which cannot be ignored. The plot of ratio $\mathrm{NO}_{3}{ }^{-} / \mathrm{Cl}^{-}$versus $\mathrm{Cl}^{-}$(Figure 8) could be used as an indicator to identify seawater intrusion and anthropogenic pollution [59]. Saline water with high concentrations of $\mathrm{Cl}^{-}$exhibited low values of $\mathrm{NO}_{3}{ }^{-} / \mathrm{Cl}^{-}$, confirming seawater intrusion. On the other hand, the increase of $\mathrm{NO}_{3}{ }^{-} / \mathrm{Cl}^{-}$values with a decrease of $\mathrm{Cl}^{-}$indicates the impact of anthropogenic activity on the shallow groundwater. The anthropogenic pollution may have a strong influence on the occurrence of $\mathrm{NO}_{3}{ }^{-}$in the groundwater. Figure 8 shows that the shallow groundwater of sample sites \#8, \#14, \#22, and \#29 were influenced by seawater intrusion, and the sample sites \#15, \#16, \#27, \#31, and \#35 were affected by nitrate contamination. Additionally, the inference is consistent with the geospatial distribution of nitrate (Figure 4) as mentioned above.

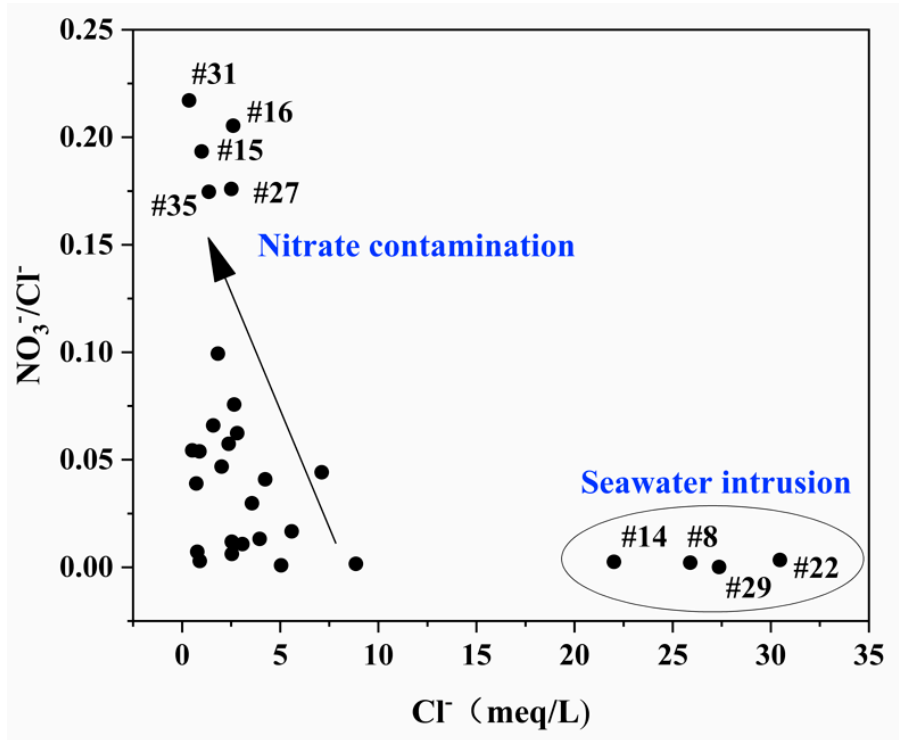

Figure 8. Scatter diagram of $\mathrm{NO}_{3}{ }^{-} / \mathrm{Cl}^{-}$vs. $\mathrm{Cl}^{-}$.

As the analysis above, the coastal aquifers are subjected to the ongoing influence of the seawater intrusion, ion exchange processes, freshwater infiltration, and mineral (carbonate and silicate) dissolution, which impact groundwater evolution. Additionally, the anthropogenic activities about agricultural pollution cannot be ignored. A summary of the main hydrochemical evolution mechanisms in the aquifer is depicted in Figure 9.

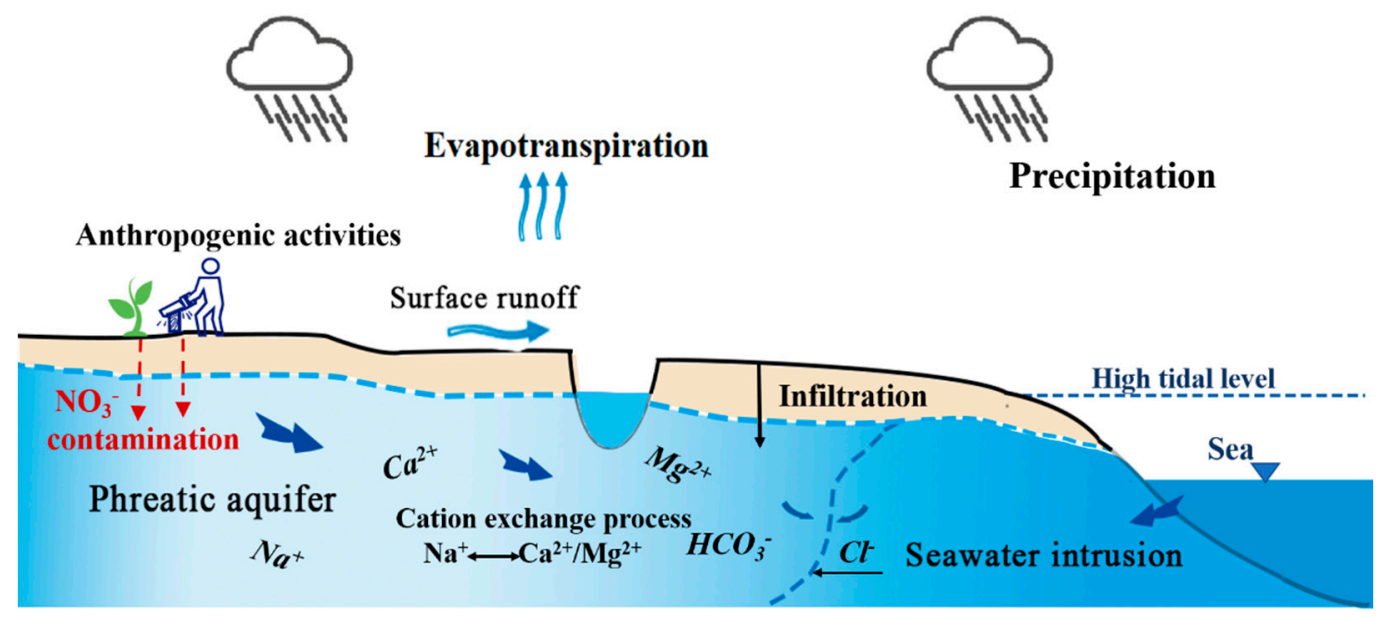

Figure 9. Conceptual model of the main hydrochemical evolution mechanisms recognized in the study area. 


\subsection{Evaluation of Groundwater Suitability in Drinking and Irrigation}

According the World Health Organization (WHO) [60] standards, the shallow groundwater analytical results of $\mathrm{pH}$, total hardness (TH), TDS, major ions, and microelements were classified for drinking purposes. As Table 3 shows, there are $20 \%, 40 \%, 13.3 \%$, and $3.3 \%$ of $\mathrm{Na}^{+}, \mathrm{K}^{+}, \mathrm{Cl}^{-}$, and $\mathrm{NH}_{4}{ }^{+}$concentrations in the entire shallow groundwater samples that exceed the WHO maximum allowable limit and the resulting undesirable effects on humans. For the microelements in shallow groundwater, it has been found that $20 \%$ of $\mathrm{Fe}, 30 \%$ of $\mathrm{Mn}$, and $6.7 \%$ of As concentrations in all samples exceed the maximum allowable limit. The higher concentrations of $\mathrm{Fe}^{2+}$ were observed in the shallow groundwater samples \#4,\#12, \#25, \#26, \#29, and \#33. The content of $\mathrm{Mn}^{2+}$ in \#4, \#5, \#7, \#14, \#23, \#26, \#27, \#29, and \#33 samples exceeded the limit of WHO standards. Additionally, the content of $\mathrm{As}^{3+}$ also in samples \#29 and \#33 exceeded the maximum allowable limit standard. According to analysis results, the $\mathrm{Ca}^{2+}, \mathrm{Mg}^{2+}, \mathrm{SO}_{4}{ }^{2-}, \mathrm{NO}_{3}{ }^{-}, \mathrm{NO}_{2}{ }^{-}, \mathrm{Cu}^{2+}, \mathrm{Al}^{3+}, \mathrm{Zn}^{2+}, \mathrm{Hg}^{2+}, \mathrm{Pb}^{2+}, \mathrm{Cd}^{2+}, \mathrm{Cr}^{6+}$, and $\mathrm{F}^{-}$concentrations in shallow groundwater of the study area were within the maximum allowable limit in the entire samples.

Table 3. Groundwater samples of the study area exceeding the allowable limits prescribed by WHO for drinking purposes.

\begin{tabular}{|c|c|c|c|}
\hline \multirow{2}{*}{$\begin{array}{l}\text { Parameters } \\
(\mathrm{mg} / \mathrm{L})\end{array}$} & \multicolumn{2}{|c|}{ WHO [60] } & \multirow{2}{*}{$\begin{array}{c}\text { Percentage of Samples Exceeding } \\
(\%)\end{array}$} \\
\hline & Desirable Limit & Maximum Allowable Limit & \\
\hline $\mathrm{pH}$ & $7-8.5$ & 9.2 & Nil \\
\hline TH & 100 & 500 & 23.3 \\
\hline TDS & 500 & 1500 & 16.7 \\
\hline $\mathrm{Na}$ & - & 200 & 20.0 \\
\hline $\mathrm{K}$ & - & 12 & 40.0 \\
\hline $\mathrm{Ca}$ & 75 & 200 & Nil \\
\hline $\mathrm{Mg}$ & 50 & 150 & Nil \\
\hline $\mathrm{Cl}$ & 250 & 600 & 13.3 \\
\hline $\mathrm{SO}_{4}{ }^{2-}$ & 200 & 400 & Nil \\
\hline $\mathrm{NO}_{3}^{-}$ & 50 & - & Nil \\
\hline $\mathrm{NH}_{4}^{+}$ & 1.5 & - & 3.3 \\
\hline $\mathrm{NO}_{2}^{-}$ & 3 & - & Nil \\
\hline $\mathrm{Fe}$ & - & 0.3 & 20.0 \\
\hline $\mathrm{Mn}$ & - & 0.1 & 30.0 \\
\hline $\mathrm{Cu}$ & - & 2.0 & Nil \\
\hline $\mathrm{Al}$ & - & 0.1 & Nil \\
\hline $\mathrm{Zn}$ & - & 3.0 & Nil \\
\hline $\mathrm{Hg}$ & - & 0.001 & Nil \\
\hline $\mathrm{Pb}$ & - & 0.01 & Nil \\
\hline As & - & 0.01 & 6.7 \\
\hline $\mathrm{Cd}$ & - & 0.003 & Nil \\
\hline $\mathrm{Cr}$ & - & 0.05 & Nil \\
\hline $\mathrm{F}$ & - & 1.5 & Nil \\
\hline
\end{tabular}

To ascertain the suitability of groundwater for any purposes, it is vital to classify the groundwater depending on its hydrochemical properties based on its TDS values [44]. According to the WHO standards, $16.7 \%$ of the samples exceed the permissible limits, which is shown in Table 3. From Table 4, $76.66 \%$ of the total samples could be used for drinking and $23.33 \%$ could be used for irrigation [61]. The classification of $\mathrm{TH}$ reveals that $70 \%$ of groundwater samples belong to the category named very hard and $30 \%$ in the hard category, indicating that the groundwater in the study area is useless for laundry work [62]. The hard groundwater could cause scaling the contact surface, plug pipes, and irrigation lines and even cause foliar scale deposits [25]. The $23.3 \%$ of total groundwater samples based on the values of TH exceeds the maximum allowable limit of total hardness for drinking purposes as the reference of WHO standards. Referring to the WHO standards and classifications of TDS and TH, most of the groundwater aquifer seems to be unsuitable for safe drinking especially near the samples 
$\# 4, \# 8, \# 14, \# 22, \# 25, \# 29$, and \#33. Water treatments and adequate processing are necessarily needed in advance if the groundwater is used for domestic potable water.

Table 4. Classification of groundwater based on TDS, total hardness (TH), sodium adsorption ration (SAR), soluble-sodium percentage (SSP).

\begin{tabular}{cccc}
\hline Quality Parameter & Ranges & Categories & Percent of Samples \\
\hline & $<500$ & Desirable for drinking & 13.33 \\
TDS & $500-1000$ & Permissible for drinking & 63.33 \\
$(\mathrm{mg} / \mathrm{L})$ & $1000-3000$ & Useful for irrigation & 23.33 \\
& $>3000$ & Unfit for drinking and irrigation & Nil \\
\hline \multirow{2}{*}{ Total hardness } & $<75$ & Soft & Nil \\
$(\mathrm{mg} / \mathrm{L})$ & $75-150$ & Moderately hard & Nil \\
& $150-300$ & Hard & 30.00 \\
& $>300$ & Very hard & 70.00 \\
\hline SAR & $<10$ & Excellent & 83.33 \\
& $10-18$ & Good & 13.33 \\
& $18-26$ & Doubtful & 3.33 \\
& $>26$ & Unsuitable & Nil \\
\hline & $<20$ & Excellent & 6.67 \\
SSP & $20-40$ & Good & 40.00 \\
& $40-60$ & Permissible & 36.67 \\
& $60-80$ & Doubtful & 10.00 \\
& $>80$ & Unsuitable & 6.67 \\
\hline
\end{tabular}

Excessive amounts of dissolved ions such as $\mathrm{Na}^{+}, \mathrm{HCO}_{3}{ }^{-}$, and $\mathrm{CO}_{3}{ }^{2-}$ in irrigation water adversely affect plants and soil texture, reducing the productivity of agriculture [63]. Salinity and indexes such as sodium absorption ratio (SAR) and soluble-sodium percentage (SSP) are important parameters for determining the suitability of groundwater for agricultural uses [10]. The relative activity of sodium ions in the exchange reaction with soil is expressed in terms of a ratio known as sodium adsorption ratio (SAR). SAR is an important parameter for determining the suitability of groundwater for irrigation because it is a measure of alkali/sodium hazard to crops [64]. Soluble-sodium percentage (SSP) is another important parameter which could assess whether groundwater contains excessive sodium, affecting the soil properties and reducing soil permeability.

SAR [65] is defined as follows (all ionic concentrations are expressed by meq/L):

$$
\mathrm{SAR}=\mathrm{Na}^{+} /\left[\left(\mathrm{Ca}^{2+}+\mathrm{Mg}^{2+}\right) / 2\right]^{1 / 2} .
$$

Soluble-sodium percentage (SSP) [66] is obtained by the following (all ionic concentrations are expressed by meq/L):

$$
\mathrm{SSP}=\mathrm{Na}^{+} \times 100 /\left(\mathrm{Na}^{+}+\mathrm{Ca}^{2+}+\mathrm{Mg}^{2+}+\mathrm{K}^{+}\right) .
$$

The classifications of groundwater samples with respect to SAR and SSP are shown in Table 4. The SAR values range from 0.64 to 18.53 with a mean value of 4.73 . Most of the water samples, except \#14, do not exceed the SAR value of 18, implying that the groundwaters within the study area are suitable for irrigation purposes. For the classification of SSP, out of 30 groundwater samples, $25(83.33 \%)$ belong to the good to permissible; $14(46.67 \%)$, excellent to good; three (10\%), doubtful to unsuitable; two $(6.67 \%)$, unsuitable categories. The SSP manifests that $93.3 \%$ of the samples are suitable for irrigation.

\section{Conclusions}

This paper focused on shallow groundwater of the estuarine coastal zone in Qidong, located in the Yangtze River estuary. The groundwater in coastal area is weakly alkaline. $\mathrm{Na}^{+}$and $\mathrm{Cl}^{-}$are the 
main factors affecting shallow groundwater salinization in the region. The prevalent water types are $\mathrm{HCO}_{3}-\mathrm{CaMg}$, followed by $\mathrm{Cl}-\mathrm{Na}$ and $\mathrm{HCO}_{3} \mathrm{Cl}-\mathrm{Na}$. The ground water chemistry can be categorized as $\mathrm{HCO}_{3}-\mathrm{CaMg}$ and $\mathrm{HCO}_{3}-\mathrm{Na}$, becoming $\mathrm{HCO}_{3} \mathrm{Cl}-\mathrm{Na}$ and $\mathrm{Cl}-\mathrm{Na}$ along the coastal strip. This finding demonstrates the impact of seawater mixing with the regional aquifer, as it undergoes a gradual freshening process.

The hydrochemical formation mechanisms of shallow groundwater were determined by combined effects of seawater intrusion and rock-water interaction (ion exchange processes, freshwater infiltration, and mineral dissolution). The intrusion of seawater in the coastal aquifer is the principal processes, but the freshening phenomenon in the discharge zone and the influence of anthropogenic activities are important and cannot be ignored.

The groundwater in study area is unsuitable for drinking based on the WHO standards and classifications of TDS and TH, as well as useless in domestic purposes unless water treatments have been undertaken in advance. On the other hand, the SAR and SSP demonstrate that more than $90 \%$ of the groundwater samples are suitable for irrigation.

Author Contributions: Conceptualization, X.G. and Y.W.; Methodology and Software, Y.W. and J.Q; Formal Analysis, Y.W. and J.Q.; Investigation and Data Curation, Y.W., S.C. and C.X.; Supervision, X.G.; Writing-Original Draft Preparation, Y.W.; Writing-Review and Editing, J.Q., X.G., S.C. and C.X. All authors have read and agreed to the published version of the manuscript.

Funding: This research was supported by the National Natural Science Foundation of China (No. 41671461).

Acknowledgments: We would like to thank Ailiang Gu for his invaluable help with editing the English text of this manuscript. The authors acknowledge technical support by the Shanghai SEP Analytical Services Co., Ltd.

Conflicts of Interest: The authors declare no conflict of interest. The funders had no role in the design of the study; in the collection, analyses, or interpretation of data; in the writing of the manuscript, or in the decision to publish the results.

\section{Appendix A}

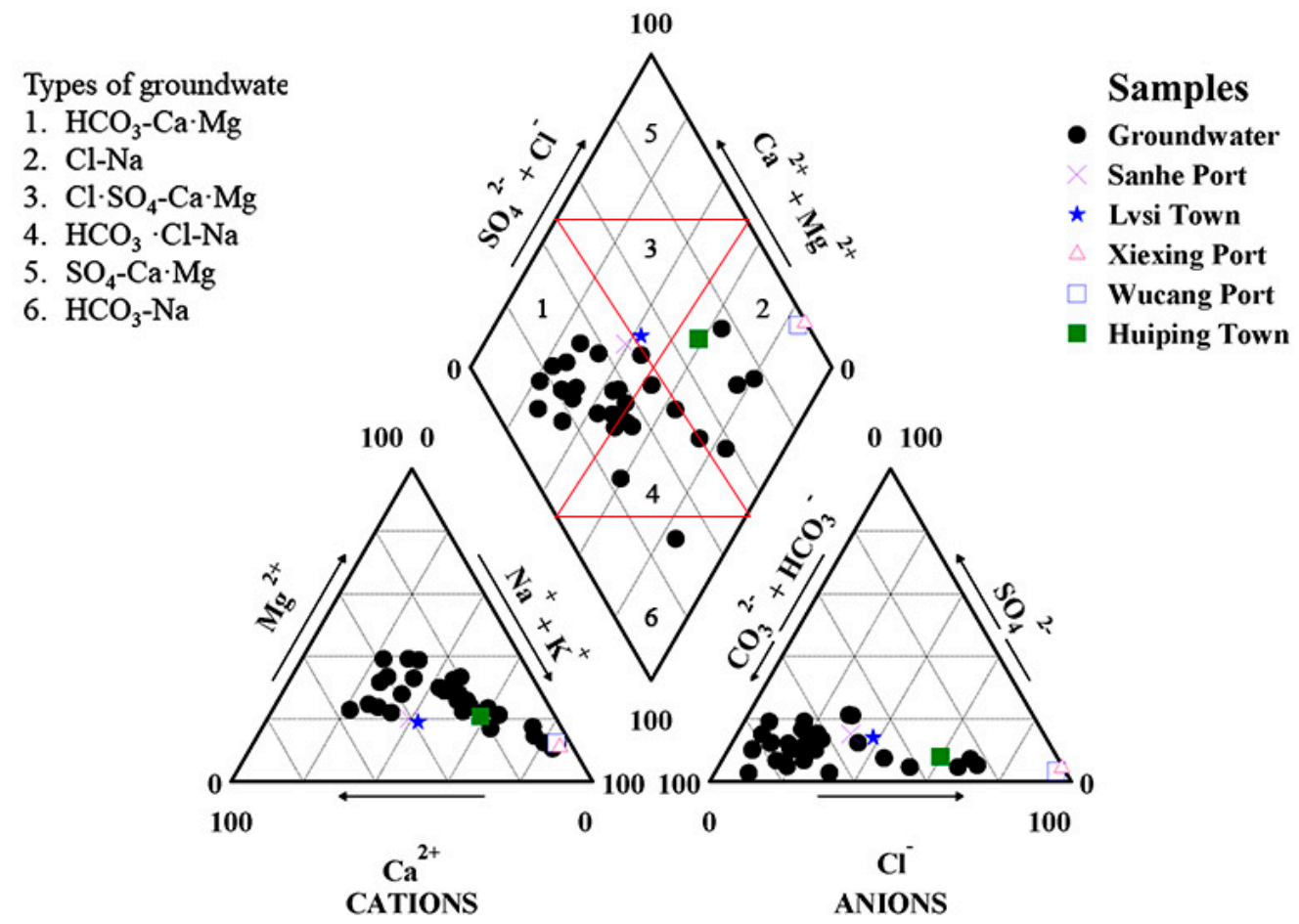

Figure A1. Piper diagram of groundwater and surface water. 
Table A1. Chemical characteristics of surface water in the study area.

\begin{tabular}{|c|c|c|c|c|c|c|c|c|c|c|c|c|}
\hline \multirow{2}{*}{\multicolumn{2}{|c|}{ Sample }} & \multirow[b]{2}{*}{ Type } & \multicolumn{10}{|c|}{ Indicator/mg $\cdot \mathrm{L}^{-1}$} \\
\hline & & & $\mathrm{Na}^{+}$ & $\mathrm{K}^{+}$ & $\mathrm{Ca}^{2+}$ & $\mathrm{Mg}^{2+}$ & $\mathrm{Cl}^{-}$ & $\mathrm{HCO}_{3}^{-}$ & $\mathrm{SO}_{4}{ }^{2-}$ & $\mathrm{NO}_{3}{ }^{-}$ & $\mathrm{NH}_{4}{ }^{+}$ & TDS \\
\hline 3 & Huiping Town & $\mathrm{Cl}-\mathrm{Na}$ & 113.0 & 130 & 36.8 & 22.7 & 203.6 & 168.4 & 36.2 & 0.41 & 1.24 & 601.00 \\
\hline 11 & Wucang Port & $\mathrm{Cl}-\mathrm{Na}$ & 2210.0 & 125.3 & 90.1 & 177.4 & 3780.0 & 151.3 & 179.6 & 1.18 & 0.65 & 6690.00 \\
\hline 17 & Xiexing Port & $\mathrm{Cl}-\mathrm{Na}$ & 8200.0 & 350.0 & 308.0 & 572.0 & $13,800.0$ & 87.9 & 844.4 & 0.73 & 0.34 & $30,000.00$ \\
\hline 30 & Lvsi Town & $\mathrm{HCO}_{3}-\mathrm{Ca} \cdot \mathrm{Mg}$ & 41.8 & 9.1 & 37.8 & 11.3 & 71.2 & 133.0 & 35.5 & 1.11 & 0.59 & 324.00 \\
\hline 3832 & Sanhe Port & $\mathrm{HCO}_{3}-\mathrm{Ca} \cdot \mathrm{Mg}$ & 33.1 & 7.7 & 34.0 & 10.2 & 47.9 & 119.6 & 31.5 & 1.38 & 0.06 & 273.00 \\
\hline
\end{tabular}




\section{References}

1. Lei, S.; Jiao, J.J. Seawater intrusion and coastal aquifer management in China: A review. Environ. Earth Sci. 2014, 72, 2811-2819.

2. Fetter, C.W. Applied Hydrogeology: International Edition; Person: London, UK, 2001.

3. Mohanty, A.K.; Rao, V.V.S.G. Hydrogeochemical, seawater intrusion and oxygen isotope studies on a coastal region in the Puri District of Odisha, India. Catena 2019, 172, 558-571. [CrossRef]

4. Werner, A.D.; Bakker, M.; Post, V.E.A.; Vandenbohede, A.; Lu, C.; Ataie-Ashtiani, B.; Simmons, C.T.; Barry, D.A. Seawater intrusion processes, investigation and management: Recent advances and future challenges. Adv. Water Resour. 2013, 51, 3-26. [CrossRef]

5. Pulido-Leboeuf, P. Seawater intrusion and associated processes in a small coastal complex aquifer (Castell de Ferro, Spain). Appl. Geochem. 2004, 19, 1517-1527. [CrossRef]

6. Seawater Intrusion in Coastal Aquifers-Concepts, Methods and Practices; Bear, J.; Cheng, H.D.; Sorek, S.; Ouazar, D.; Herrera, I.J.T. (Eds.) Springer: Berlin, Germany, 1999; p. 14.

7. Psychoyou, M.; Mimides, T.; Rizos, S.; Sgoubopoulou, A.J.D. Groundwater hydrochemistry at Balkan coastal plains-The case of Marathon of Attica, Greece. Desalination 2007, 213, 230-237. [CrossRef]

8. Helstrup, T.; Jørgensen, N.O.; Banoeng-Yakubo, B. Investigation of hydrochemical characteristics of groundwater from the Cretaceous-Eocene limestone aquifer in southern Ghana and southern Togo using hierarchical cluster analysis. Hydrogeol. J. 2007, 15, 977-989. [CrossRef]

9. Mondal, N.C.; Singh, V.P.; Singh, S.; Singh, V.S. Hydrochemical characteristic of coastal aquifer from Tuticorin, Tamil Nadu, India. Environ. Monit. Assess. 2011, 175, 531-550. [CrossRef]

10. Selvam, S.; Manimaran, G.; Sivasubramanian, P. Hydrochemical characteristics and GIS-based assessment of groundwater quality in the coastal aquifers of Tuticorin corporation, Tamilnadu, India. Appl. Water Sci. 2013, 3, 145-159. [CrossRef]

11. Su, Y.-H.; Feng, Q.; Zhu, G.-F.; Si, J.-H.; Zhang, Y.-W. Identification and evolution of groundwater chemistry in the ejin sub-basin of the heihe river, northwest china1 1 project supported by the national natural science foundation of china (Nos. 40671010 and 40501012). Pedosphere 2007, 17, 331-342. [CrossRef]

12. Hamed, Y.; Dhahri, F. Hydro-geochemical and isotopic composition of groundwater, with emphasis on sources of salinity, in the aquifer system in Northwestern Tunisia. J. Afr. Earth Sci. 2013, 83, 10-24. [CrossRef]

13. Carol, E.; Kruse, E.; Mas-Pla, J. Hydrochemical and isotopical evidence of ground water salinization processes on the coastal plain of Samborombón Bay, Argentina. J. Hydrol. 2009, 365, 335-345. [CrossRef]

14. Salem, Z.E.; Al Temamy, A.M.; Salah, M.K.; Kassab, M. Origin and characteristics of brackish groundwater in Abu Madi coastal area, Northern Nile Delta, Egypt. Estuar. Coast. Shelf Sci. 2016, 178, 21-35. [CrossRef]

15. Yang, Q.; Xiao, H.; Zhao, L.; Yang, Y.; Li, C.; Zhao, L.; Yin, L. Hydrological and isotopic characterization of river water, groundwater, and groundwater recharge in the Heihe River basin, northwestern China. Hydrol. Process. 2011, 25, 1271-1283. [CrossRef]

16. Medici, G.; West, L.J.; Chapman, P.J.; Banwart, S.A. Prediction of contaminant transport in fractured carbonate aquifer types: A case study of the Permian Magnesian Limestone Group (NE England, UK). Environ. Sci. Pollut. Res. 2019, 26, 24863-24884. [CrossRef]

17. Kammoun, S.; Trabelsi, R.; Re, V.; Zouari, K.; Henchiri, J. Groundwater quality assessment in semi-arid regions using integrated approaches: The case of Grombalia aquifer (NE Tunisia). Environ. Monit. Assess. 2018, 190, 87. [CrossRef]

18. Xanke, J.; Goeppert, N.; Sawarieh, A.; Liesch, T.; Kinger, J.; Ali, W.; Hötzl, H.; Hadidi, K.; Goldscheider, N. Impact of managed aquifer recharge on the chemical and isotopic composition of a karst aquifer, Wala reservoir, Jordan. Hydrogeol. J. 2015, 23, 1027-1040. [CrossRef]

19. Bouzourra, H.; Bouhlila, R.; Elango, L.; Slama, F.; Ouslati, N. Characterization of mechanisms and processes of groundwater salinization in irrigated coastal area using statistics, GIS, and hydrogeochemical investigations. Environ. Sci. Pollut. Res. 2015, 22, 2643-2660. [CrossRef]

20. Gibbs, R.J. Mechanisms controlling world water chemistry. Science 1970, 170, 1088-1090. [CrossRef]

21. Barlow, P.M.; Reichard, E.G. Saltwater intrusion in coastal regions of North America. Hydrogeol. J. 2010, 18, 247-260. [CrossRef]

22. Vandenbohede, A.; Lebbe, L. Occurrence of salt water above fresh water in dynamic equilibrium in a coastal groundwater flow system near De Panne, Belgium. Hydrogeol. J. 2006, 14, 462-472. [CrossRef] 
23. Ghiglieri, G.; Carletti, A.; Pittalis, D. Analysis of salinization processes in the coastal carbonate aquifer of Porto Torres (NW Sardinia, Italy). J. Hydrol. 2012, 432, 435-451. [CrossRef]

24. Wang, Y.; Jiao, J.J. Origin of groundwater salinity and hydrogeochemical processes in the confined Quaternary aquifer of the Pearl River Delta, China. J. Hydrol. 2012, 438, 1121-1124. [CrossRef]

25. Sebei, A.; Slama, T.; Helali, M.A. Hydrochemical characterization and geospatial analysis of groundwater quality in Cap Bon region, northeastern Tunisia. Environ. Earth Sci. 2018, 77, 557. [CrossRef]

26. Chacha, N.; Njau, K.N.; Lugomela, G.V.; Muzuka, A.N.N. Hydrogeochemical characteristics and spatial distribution of groundwater quality in Arusha well fields, Northern Tanzania. Appl. Water Sci. 2018, 8, 118. [CrossRef]

27. Rabeiy, R.E. Assessment and modeling of groundwater quality using WQI and GIS in Upper Egypt area. Environ. Sci. Pollut. Res. 2018, 25, 30808-30817. [CrossRef]

28. Ali, S.A.; Ali, U. Hydrochemical characteristics and spatial analysis of groundwater quality in parts of Bundelkhand Massif, India. Appl. Water Sci. 2018, 8, 39. [CrossRef]

29. Brindha, K.; Elango, L. Groundwater quality zonation in a shallow weathered rock aquifer using GIS. Geo-Spat. Inf. Sci. 2012, 15, 95-104. [CrossRef]

30. Vittecoq, B.; Reninger, P.A.; Violette, S.; Martelet, G.; Dewandel, B.; Audru, J.C. Heterogeneity of hydrodynamic properties and groundwater circulation of a coastal andesitic volcanic aquifer controlled by tectonic induced faults and rock fracturing-Martinique island (Lesser Antilles-FWI). J. Hydrol. 2015, 529, 1041-1059. [CrossRef]

31. Liu, M.; Yang, Y.; Hou, L.; Xu, S.; Ou, D.; Zhang, B.; Liu, Q. Chlorinated organic contaminants in surface sediments from the Yangtze Estuary and nearby coastal areas, China. Mar. Pollut. Bull. 2003, 46, 672-676. [CrossRef]

32. Zhao, S.; Feng, C.; Wang, D.; Tian, C.; Shen, Z.Y. Relationship of metal enrichment with adverse biological effect in the Yangtze Estuary sediments: Role of metal background values. Environ. Sci. Pollut. Res. 2014, 21, 464-472. [CrossRef]

33. Song, B.; Zhang, X.; Fang, Z. Mechanism of chemical evolution for Quaternary groundwater in Yangtze River estuarine region. Acta Geogr. Sin.-Chin. Ed. 2000, 55, 218-226.

34. Wang, S.; Sun, J.; Li, Z. Groundwater quality evaluation in the delta area of the Yangtze River. Hydrogeol. Eng. Geol. 2005, 32, 30-33.

35. Xuan, J.L.; Huang, D.; Zhou, F.; Zhu, X.H.; Fan, X. The role of wind on the detachment of low salinity water in the Changjiang Estuary in summer. J. Geophys. Res.: Ocean. 2012, 117. [CrossRef]

36. Qiao, J.; Long, J.; Xu, D. Preliminary study in geochemical characteristics of seawater intrusion in the coastal region north wing of the Yangtze River Estuary. Mar. Sci. Bull. /Haiyang Tongbao 2011, 30, $200-205$.

37. Li, P.; Yang, S.; Dai, S.; Zhang, W. Accretion/erosion of the subaqueous delta at the Yangtze Estuary in recent 10 years. Acta Geogr. Sin.-Chin. Ed. 2007, 62, 707.

38. Bahar, M.M.; Reza, M.S. Hydrochemical characteristics and quality assessment of shallow groundwater in a coastal area of Southwest Bangladesh. Environ. Earth Sci. 2010, 61, 1065-1073. [CrossRef]

39. Xiaotong, H. Study on the Coupled Numerical Simulation of Groundwater Flow, Land Subsidence and Freshwater Salinisation in Nantong Area. Master's Thesis, Nanjing University, Nanjing, China, 2016.

40. Qi, W.; Qingshan, M.; Zu, J.L. Probe into deep groundwater salinization genesis in nantong city. Coal Geol. China 2017, 29, 41-45.

41. Luo, Z.J.; Zhang, Y.Y.; Shi, C.H. Three-dimensional numerical model for groundwater resource evaluation and plan in loose Quaternary sediments in Nantong. Water Resour. Prot. 2009, 25, 19-23.

42. Bo, K. The Study of Groundwater Evolution and Rational Exploitation and Utilizing in Jiangsu Coastal Area. Ph.D. Thesis, Jilin University, Jilin, China, 2017.

43. Hui-fang, Z.; Hong-bing, T.; Xi-ying, Z.; Wen-jie, Z.; Xue, S. Recharge source, hydrochemical characteristics and formation mechanism of groundwater in Nantong, Jiangsu Province. Geochimica 2011, 40, 566-576.

44. Freeze, R.A.; Cherry, J.A. Groundwater; Prentice-Hall: Englewood Cliffs, NJ, USA, 1979.

45. Lei, Z.; Yang, S.; Xu, Z.; Vachaud, G. Preliminary investigation of the spatial variability of soil properties. J. Hydraul. Eng. 1985, 9, 10-21.

46. Tesoriero, A.J.; Spruill, T.B.; Eimers, J.L. Geochemistry of shallow ground water in coastal plain environments in the southeastern United States: Implications for aquifer susceptibility. Appl. Geochem. 2004, 19, 1471-1482. [CrossRef] 
47. Piper, A.M. A graphic procedure in the geochemical interpretation of water-analyses. Trans. Am. Geophys. Union 1944, 25, 914-928. [CrossRef]

48. Hiscock, K.M.; Bense, V.F.; Hiscock, K.M.; Bense, V.F. Hydrogeology: Principles and Practice; Wiley: Hoboken, NJ, USA, 2007.

49. De Montety, V.; Radakovitch, O.; Vallet-Coulomb, C.; Blavoux, B.; Hermitte, D.; Valles, V. Origin of groundwater salinity and hydrogeochemical processes in a confined coastal aquifer: Case of the Rhône delta (Southern France). Appl. Geochem. 2008, 23, 2337-2349. [CrossRef]

50. Manno, E.; Vassallo, M.; Varrica, D.; Dongarrà, G.; Hauser, S. Hydrogeochemistry and water balance in the coastal wetland area of "Biviere di Gela," Sicily, Italy. Water Air Soil Pollut. 2007, 178, 179-193. [CrossRef]

51. Vengosh, A.; Rosenthal, E. Saline groundwater in Israel: Its bearing on the water crisis in the country. J. Hydrol. 1994, 156, 389-430. [CrossRef]

52. Tlili-Zrelli, B.; Hamzaoui-Azaza, F.; Gueddari, M.; Bouhlila, R. Geochemistry and quality assessment of groundwater using graphical and multivariate statistical methods. A case study: Grombalia phreatic aquifer (Northeastern Tunisia). Arab. J. Geosci. 2013, 6, 3545-3561. [CrossRef]

53. García, G.M.; Hidalgo, M.d.V.; Blesa, M.A. Geochemistry of groundwater in the alluvial plain of Tucuman province, Argentina. Hydrogeol. J. 2001, 9, 597-610. [CrossRef]

54. Cardona, A.; Carrillo-Rivera, J.J.; Huizar-Álvarez, R.; Graniel-Castro, E. Salinization in coastal aquifers of arid zones: An example from Santo Domingo, Baja California Sur, Mexico. Environ. Geol. 2004, 45, 350-366. [CrossRef]

55. Appelo, C.; Postma, D. Geochemistry, Groundwater and Pollution, 2nd ed.; August Aimé Balkema: Rotterdam, The Netherlands, 2005.

56. Martínez, D.; Bocanegra, E. Hydrogeochemistry and cation-exchange processes in the coastal aquifer of Mar Del Plata, Argentina. Hydrogeol. J. 2002, 10, 393-408. [CrossRef]

57. Richter, B.C.; Kreitler, C.W.; Bledsoe, B.E. Identification of Sources of Ground-Water Salinization Using Geochemical Techniques; US Environmental Protection Agency, Office of Research and Development: Washington, DC, USA, 1991; p. 273.

58. Schoeller, H. Groundwater Studies-An International Guide for Research and Practice. In Geochemistry of Groundwater; UNESCO: Paris, France, 1977; Chapter 15.

59. Askri, B. Hydrochemical processes regulating groundwater quality in the coastal plain of Al Musanaah, Sultanate of Oman. J. Afr. Earth Sci. 2015, 106, 87-98. [CrossRef]

60. WHO. Guidelines for Drinking-Water Quality; World Health Organization: Geneva, Switzerland, 2011.

61. Davis, S.N.; De Wiest, R.J. Hydrogeology; Wiley: New York, NY, USA, 1966.

62. Sawyer, C.N.; McCarty, P.L. Chemistry for Sanitary Engineers; McGraw-Hill: New York, NY, USA, 1967.

63. Todd, D.K. Groundwater Hydrology; Wiley: New York, NY, USA, 1980.

64. Subramani, T.; Elango, L.; Damodarasamy, S. Groundwater quality and its suitability for drinking and agricultural use in Chithar River Basin, Tamil Nadu, India. Environ. Geol. 2005, 47, 1099-1110. [CrossRef]

65. Richards, L.A. Diagnosis and Improvement of Saline and Alkali Soils; LWW: Philadelphia, PA, USA, 1954; Volume 78.

66. Wilcox, L. Classification and Use of Irrigation Waters; US Department of Agriculture: Washington, DC, USA, 1955.

(C) 2020 by the authors. Licensee MDPI, Basel, Switzerland. This article is an open access article distributed under the terms and conditions of the Creative Commons Attribution (CC BY) license (http://creativecommons.org/licenses/by/4.0/). 